John Christodoulou ORCID iD: 0000-0002-8431-0641

Wendy Gold ～ORCID iD: 0000-0003-1808-0646

\title{
Genome-wide transcriptomic and proteomic studies of Rett syndrome mouse models identify common signalling pathways and cellular functions as potential therapeutic targets.
}

Rahul Krishnaraj ${ }^{1}$, Florencia Haase ${ }^{3}$, Bronte Coorey ${ }^{3}$, Edward J Luca ${ }^{2}$, Ingar Wong ${ }^{3}$, Alexandra Boyling ${ }^{3}$, Carolyn Ellaway ${ }^{1,4,5}$, John Christodoulou* ${ }^{1,4,5,6}$ and Wendy A Gold*1,3,4

${ }^{1}$ Genetic Metabolic Disorders Research Unit, Western Sydney Genetics Program, The Children’s Hospital at Westmead, Sydney, NSW, Australia

${ }^{2}$ The University of Sydney, University Library, Sydney, NSW, Australia

${ }^{3}$ Molecular Neurobiology Research Lab, Kids Research, Sydney Children’s Hospitals Network, Westmead, Australia

${ }^{4}$ Discipline of Child and Adolescent Health, The University of Sydney, Sydney, NSW Australia

${ }^{5}$ Genetic Medicine, Sydney Medical School, The University of Sydney, Sydney, NSW Australia

${ }^{6}$ Brain and Mitochondrial Research Group, Murdoch Children’s Research Institute, and Department of Paediatrics, Melbourne Medical School, University of Melbourne, Melbourne, Australia

* Co-last authors

This is the author manuscript accepted for publication and undergone full peer review but has not been through the copyediting, typesetting, pagination and proofreading process, which may lead to differences between this version and the Version of Record. Please cite this article as doi: 10.1002/humu.23887. 


\author{
Correspondence to Wendy Gold \\ Molecular Neurobiology Research Lab \\ Kids Research \\ The Children’s Hospital at Westmead, \\ Locked Bag 4001 \\ Sydney, NSW, Australia \\ Email: wendy.gold@sydney.edu.au
}

\begin{abstract}
The discovery that Rett syndrome is caused by mutations in the MECP2 gene has provided a major breakthrough in our understanding of the disorder. However, despite this, there is still limited understanding of the underlying pathophysiology of the disorder hampering the development of curative treatments. Over the years, a number of animal models have been developed contributing to our knowledge on the role of MECP2 in development and improving our understanding of how subtle expression levels affect brain morphology and function. Transcriptomic and proteomic studies of animal models are useful in identifying perturbations in functional pathways and providing avenues for novel areas of research into disease. This review focuses on published transcriptomic and proteomic studies of mouse models of Rett syndrome with the aim of providing a summary of all the studies, the reported dysregulated genes and functional pathways that are found to be perturbed. The 36 articles identified highlighted a number of dysfunctional pathways as well as perturbed biological networks and cellular functions including synaptic dysfunction and neuronal transmission, inflammation and mitochondrial dysfunction. These data
\end{abstract}


reveal biological insights that contribute to the disease process which may be targeted to investigate curative treatments.

\section{KEYWORDS:}

Rett syndrome, $M E C P 2$, transcriptomic, proteomic, mouse model, pathways

\section{INTRODUCTION}

Rett syndrome (Rett syndrome; MIM\# 312750) is a severe X-linked neurological disorder which mostly affects females and is the second most common cause of severe intellectual disability in females after Down syndrome (Ellaway and Christodoulou, 2001). Rett syndrome is recognised as a disorder of neuronal plasticity characterized by the loss of intellectual functioning, fine and gross motor skills, communication skills, deceleration of head growth and the development of stereotypic hand movements occurring after a period of apparently normal development (Neul et al., 2010). The disorder is mostly caused by mutations in the gene encoding Methyl CpG binding protein 2 (MECP2) (Amir et al., 1999), a multifunctional protein which is highly expressed in the brain. The MECP2 gene is located on the long arm of the $\mathrm{X}$ chromosome at the Xq28 locus (Liyanage and Rastegar, 2014) and due to alternative splice sites, gives rise to 2 distinct isoforms, MeCP2e1 and MeCP2e2 (Kriaucionis and Bird, 2004, Mnatzakanian et al., 2004). MeCP2 was first purified in 1992, where it was identified as a chromatin associated nuclear protein capable of binding methylated CpG sites (Lewis et al., 1992). The protein is ubiquitously expressed but found to be most abundantly expressed in mature neurons (Kriaucionis and Bird, 2004). Initially, MeCP2 was believed to function as a transcriptional repressor, given its ability to bind methylated DNA and recruit chromatin remodelling complexes containing histone deacetylase (HDAC) enzymes (Jones et al., 1998, Nan et al., 
1998). However, more recent studies have demonstrated a MeCP2-mediated mechanism for activation of multiple genes, including Brain Derived Neurotrophic Factor (BDNF) and Glucose Transporter 3 (GLUT3) (Chahrour et al., 2008, Chen et al., 2013). MeCP2 also regulates microRNA processing (Cheng et al., 2014) and is also considered an epigenetic regulator (McGraw et al., 2011). It is now widely accepted that expression of MeCP2 is critical for maintaining normal neuronal and synaptic function. Many studies have been conducted on murine and patient samples (e.g. blood and post-mortem brain) to better understand the disorder and identify potential therapies. Following the identification of MECP2, these studies have led to the discovery of additional disease genes, such as Cyclin-dependent kinase-like 5 (CDKL5), Forkhead box protein G1 (FOXG1), Myocyte-specific enhancer factor 2C (MEF2C) and Transcription factor 4 (TCF4) (Armani et al., 2012, Evans et al., 2005, Philippe et al., 2010). Pathogenic variants in these genes, albeit to a lesser degree, are also associated with Rett syndrome, and display clinical phenotypes that overlap with this disorder.

Recent estimates recognize that around 95\% of classical Rett syndrome cases and $75 \%$ of atypical Rett syndrome cases have mutations in MECP2 (Krishnaraj et al., 2017). To date, over 900 unique variants have been identified within the MECP2 gene with about 500 being pathogenic or likely pathogenic and the rest being benign, likely benign, or VOUS (variants of unknown significance) variants (Krishnaraj et al., 2017). Before the ground-breaking discovery in 1999 that pathogenic variants in MECP2 caused Rett syndrome, the diagnosis of Rett syndrome was based purely on clinical diagnostic criteria as no useful biomarkers of the disorder or genes had been identified. Despite this discovery, due to the complex nature of the disorder, the diagnosis of Rett syndrome still relies largely on the clinical diagnostic criteria and 
the exclusion of differential diagnoses (Gold et al., 2018). In addition, effective treatments remain to be identified and treatment is still largely symptomatic. A better understanding of the underlying biological, genetic, transcriptomic and proteomic architecture of the disorder and the functional pathways would significantly improve prospects for novel targeted therapies for Rett syndrome patients.

Transcriptomic and proteomic studies have been successful in identifying new candidate genes and proteins, providing a better understanding of the underlying pathophysiology, identifying perturbations in functional pathways, and providing avenues for novel areas of research. In addition to the data generated for a specific research question, there lies a wealth of additional untapped information potentially available within these "omic" studies. This then raises the question as to whether we can learn anything new from previously conducted studies through comparing existing data sets and ultimately extracting valuable information by conducting metaanalysis. A notable example of utilizing omic data within the Rett syndrome research field is the recent study by Shovlin and Tropea that delineated transcriptomic data from human Rett syndrome patient samples, to present trends in differential gene expression for investigating broader research questions (Shovlin and Tropea, 2018).

A compelling approach to unravel novel molecular insights into the role of MeCP2 and the pathophysiology of Rett syndrome is genome-wide expression (transcriptomic) profiling and proteomic profiling. The objectives of transcriptomic profiling, whether it is using microarrays or RNA sequencing (RNA-Seq), and proteomic profiling, are to quantitate and compare gene and protein expression profiles of two or more samples in order to detect differentially expressed genes and proteins. In addition to single genes and proteins, identifying dysregulated and 
overrepresented functional pathways, biological networks and cellular functions may also reveal novel biological insights that contribute to the disease process.

In this review, we focus on published transcriptomic and proteomic studies that were performed in mouse models of Rett syndrome, highlight the main findings and discuss where future research efforts in this field should be directed. The aim of this review is to provide a summary of all the transcriptomic and proteomic studies conducted in mouse models of Rett syndrome studies, to highlight common dysregulated genes and perturbed functional pathways, biological networks and cellular functions salient to Rett syndrome.

\section{Study Characteristics}

A comprehensive list of all the studies are outlined in Table 1. Studies were conducted on a range of tissue samples, primarily in the brain given the predominant neurological nature of Rett syndrome. Transcriptomic studies were conducted on various Mecp2-deficient mouse models. Most studies were conducted in males, with two exclusively in females (Bedogni et al., 2016, Zhao et al., 2017), and one study using both genders (Johnson et al., 2017). The studies were mostly carried out using knock out mice (null), with a small proportion in Mecp2-knock in mice (Mecp2 ${ }^{\mathrm{R} 270 \mathrm{X}}$, $M e c p 2^{\mathrm{G} 273 \mathrm{X}}$, Mecp $^{308}$, Mecp $^{\mathrm{T} 158 \mathrm{~A}-\mathrm{Tavi}}$, Mecp2 ${ }^{\mathrm{R} 106 \mathrm{~W}-\mathrm{Tavi}}$ ) (Baker et al., 2013, Delepine et al., 2015, Gabel et al., 2015, Johnson et al., 2017), and Mecp2 overexpressing mice (Tg) (Ben-Shachar et al., 2009, Chahrour et al., 2008, Chen et al., 2015, Samaco et al., 2012).

In an attempt to identify region specific gene expression, studies were conducted on individual brain regions and cells isolated from these regions. These included the cortex (Tudor et al., 2002, Urdinguio et al., 2008, Kishi et al., 2016, Pacheco et al., 
2017), visual cortex (Gabel et al., 2015, Renthal et al., 2018), the cerebellum (BenShachar et al., 2009, Gabel et al., 2015, Jordan et al., 2007, Mellen et al., 2012, Mellen et al., 2017, Sanfeliu et al., 2019, Urdinguio et al., 2008), whole brain (Nuber et al., 2005, Kriaucionis et al., 2006, Guo et al., 2014), the whole hippocampus (Baker et al., 2013, Tudor et al., 2002) and the amygdala (Samaco et al., 2012). Studies were also conducted on cell sources originated from distinct regions of the brain including forebrain (Tudor et al., 2002), hypothalamus (Chahrour et al., 2008, Chen et al., 2015), midbrain (Urdinguio et al., 2008) and striatum (Zhao et al., 2013), granule cells of the dentate gyrus hippocampal region (Smrt et al., 2007), embryonic cortical neurons (Bedogni et al., 2016, Vacca et al., 2016), and excitatory and inhibitory cortical neurons (Johnson et al., 2017). Two studies used a combination of four distinct neuronal cell populations including thick tufted pyramidal neurons from the motor cortex, fast-spiking parvalbumin-positive interneurons from the motor cortex, noradrenergic locus coeruleus neurons and cerebellar Purkinje cells (Ehrhart et al., 2016, Sugino et al., 2014). Other studies used astrocytes (Delepine et al., 2015, Yasui et al., 2013) and microglia and peritoneal macrophages (Cronk et al., 2015), whilst others used cardiovascular progenitor cells (Hara et al., 2015) and cortical callosal projection neurons (Kishi et al., 2016). Studies using cell sources not originating from brain regions include the use of fibroblasts (Orlic-Milacic et al., 2014), skeletal muscle (Gold et al., 2014) and blood (Sanfeliu et al., 2019). Sample sizes of the studies varied greatly with the highest sample size being 205 (Sanfeliu et al., 2019) and the others varying between 1 and 100 samples. The age of mice used in the studies varied between embryonic, juvenile and mature with the youngest being E15 (Vacca et al., 2016, Bedogni et al., 2016) and the eldest 25 weeks (Tudor et al., 2002). 
The proteomic studies identified were conducted on three different Mecp2 mouse models: Mecp2-null, $M e c p 2^{308}$ and $M e c p 2^{J a e}$ mice (Cortelazzo et al., 2017, Matarazzo and Ronnett, 2004, Pacheco et al., 2017). The ages of mice ranged from 2 weeks to 12 months old. Two studies were conducted on male mice (Matarazzo and Ronnett, 2004, Pacheco et al., 2017) with one study on female mice (Cortelazzo et al., 2017). Two studies were conducted on brain regions (Matarazzo and Ronnett, 2004, Pacheco et al., 2017) and one on plasma (Cortelazzo et al., 2017).

\section{Analysis platforms used:}

Oligonucleotide microarrays were the most extensively used method for the transcriptomic studies, especially the Affymetrix GeneChip and Mouse Exon subfamilies of microarrays. Other platforms such as the Affymetrix Mu11k and MGU74A arrays, Affymetrix U430 arrays, ADDER, cDNA microarrays, Illumina, and Agilent were also used. Interestingly, in experiments carried out after 2012, next generation sequencing technologies started becoming a more predominant platform of choice. Data analysis approaches varied in stringency between experiments, with cutoff values ranging from $\mathrm{p}<0.05$ to $\mathrm{p}<0.005$ and fold change (fc) from $>1.2(<0.67)$ to $>2 \quad(<0.5)$. These different methodologies are of great consequence to the interpretation of data as subtle changes caused by Mecp2 deficiency may be reported to be important in the less stringent tests which do not reflect the real function of Mecp2 (Raman et al., 2018). The opposite can also happen, as too few genes may be reported in more stringent tests, hence 'loosing' critical data. One would expect to find a larger list of potential dysregulated genes in the less stringent tests $(p<0.05$; $\left.f_{c}>1.2\right)$ than the more stringent ones $\left(p<0.005\right.$; $\left.f_{c}>2\right)$, however this is not always the case which may be a reflection of the technical and design differences between the 
studies such as sample size, statistical cut-offs, mouse models, statistical power, ages, sex and anatomical regions studied.

The three proteomic studies used slightly different protein analysis and quantification methods, with Matarazzo and Ronnett using 2D gel electrophoresis and Q-T of mass spectrometry (Matarazzo and Ronnett, 2004). Cortelazzo et al used 2D and MALDIToF/ToF (Cortelazzo et al., 2017), whilst Pacheco et al used an in gel tryptic digest and LC-MS/MS (Pacheco et al., 2017).

\section{Common differentially expressed genes and pathways}

The most striking evidence emanating from this review is the lack of concordance in the dysregulated gene lists between the different studies. This may be attributed to a number of aspects including the fact that no two studies conducted gene expression profiling in the same mouse model, in the same tissue and at the same age. It would be expected that studies using the same, or similar sources of material would have a higher degree of concordance in their differential gene expression lists, however this is not the case, which highlights the complexity of the disorder and how delicately Mecp2 regulates gene expression both spatially and temporally. A collation of the highlighted differentially expressed genes in these studies did reveal a few genes that showed altered expression across three or more studies which include Irak1, Efna5, Fabp7, Fkbp5, Plagl1, Fgf11, Homer2, Nsdhl and Sgk1. However, as no metaanalysis have been conducted on the raw data from all, or a subset of these studies, it is difficult to determine whether these genes are an under-represented list or indeed a true reflection of commonly dysregulated genes.

Owing to such a small number of commonly dysregulated genes amongst these studies, another approach to better understand the aetiology of Rett syndrome is to 
interrogate groups of dysregulated genes that fall into distinct functional signalling pathways and biological networks. A comparison of altered pathways as opposed to individual genes may overcome the variability observed between each experiment. These variabilities may be due to biological sample differences, experimental noise and differences in experimental and analysis approaches, or they could equally be valid discrepancies due to the tight temporal and spatial gene regulation of Mecp2. Either way, grouping differentially expressed genes that fall into the same functional molecular pathways may provide more insight into the biological pathways, providing new directions for therapeutic interventions.

Not all the studies ascribed groups of genes to specific biological networks, pathways or cellular functions and mechanisms. However, those that did map the differential gene expression to pathways and cellular functions highlighted the diversity of the pathways, attesting to the great complexity of the disease. Several studies reported dysregulation in the NF- $\mathrm{B}$, TNF and TLR signalling pathways. In addition, perturbations in biological mechanisms and specific cellular functions associated with neuronal migration, immune response, stress response, mitochondrial dysfunction, lipid metabolism, neuronal maturation, imprinting, and those relating to synaptic function, specifically synaptogenesis, plasticity, function and transmission were also highlighted.

\section{Dysregulated NF-кB, TLR and TNF signalling pathways:}

Several studies reported an upregulation in the expression of the Interleukin-1 receptor-associated kinase (Irak1) gene (Jordan et al., 2007, Kishi et al., 2016, Urdinguio et al., 2008) implicating the NF- $\mathrm{B}$, TNF and TLR signalling pathways. The transcription factor NF- $\mathrm{BB}$ controls the expression of many genes encoding 
cytokines involved in inflammation, TNF is a pro-inflammatory cytokine involved in a number of biological processes including the immune response, and the TLR signalling pathway can lead to pro-inflammatory cytokine genes being activated and transcribed. This inflammatory response most likely mediates neuro-inflammation and may contribute to neuronal dysfunction in the brains of individuals with Rett syndrome.

This concordance in Irak1expression was despite different brain regions and age of mice being investigated (cortical callosal projection neurons in 2 week old Mecp2 ${ }^{-/ Y}$ mice (Kishi et al., 2016), cortex, midbrain and cerebellum in Mecp2 ${ }^{-/ Y}$ mice aged between 6 and 10 weeks (Urdinguio et al., 2008), and cerebellum of male Mecp $2^{\mathrm{tm} 1.1 \mathrm{Jae} / \mathrm{Y}}$ and $M e c p 2^{\mathrm{tm} 1.1 \mathrm{Bird} / \mathrm{Y}}$ mice (Jordan et al., 2007)) and suggests the activation of the signalling pathways is a pervasive feature of Rett syndrome and not restricted to brain region or mouse age. Irak1 is a serine/threonine kinase that is activated by receptors IL1R and TLRs resulting in the translocation of NF- $\kappa$ B into the nucleus and the transcription of pro-inflammatory cytokines (Janssens and Beyaert, 2003). More recently, IRAK1 has been shown to play a key role in the NF-kB signalling pathway, a pathway which is closely associated with neuronal development and its consequent dysregulation can result in neurodegenerative diseases (Gutierrez and Davies, 2011). In addition, and pertinent to Rett syndrome, Kishi et al reported that alleviating the abnormal NF- $\kappa \mathrm{B}$ signalling pathway extends the life span of Mecp2-null mice (Kishi et al., 2016), confirming the importance of this pathway in the disorder. As Irak1 expression is central to the functioning of this pathway, and the abnormally increased expression of Irak1 is associated with Mecp2 loss of function, significant interest is gathering in the investigation of the possible role of IRAK1 regulation in the NF- $\mathrm{BB}$ pathway and the pathogenesis of Rett syndrome. A 
dysregulated immune-inflammatory response implicating the NF- $\mathrm{B}$ pathway has more recently been observed by Sanfeliu et al in brains and blood of mice (Sanfeliu et al., 2019). However, although the authors did not specifically mention Irak1, the overall findings confirm the immune-inflammatory response in Rett syndrome mouse models. Finally, it must be noted that the Irak1 locus lies adjacent to the Mecp2 locus on the X chromosome and the apparent increase in expression has been proposed hold a 'bystander' effect of Mecp2 deficiency.

Studies also reported a significant dysregulation in genes enriched in the TNFmediated signalling pathway. Interestingly, these studies conducted by Vacca et al and Cronk et al used different cells of the brain, with Vacca et al testing embryonic cortical cells from male $M e c p 2^{-Y}$ mice and Cronk et al testing microglia and peritoneal macrophages from Mecp $2^{\text {Tm1.1Bird }}$ mice, suggesting again a pervasive response (Cronk et al., 2015, Vacca et al., 2016).

\section{Dysregulated biological networks and cellular functions:}

\section{Mitochondrial function:}

The role of mitochondrial dysfunction in Rett syndrome is well established and strongly supported by these studies as well as from human studies using blood samples (Shulyakova et al., 2017). In these transcriptomic murine studies, despite using different tissues, both Gold et al who tested skeletal muscle from 6 and 12 week old male $M е с p 2^{-/ Y}$ mice and Kriaucionis et al who tested whole brains from P70 male $\operatorname{Mecp}^{-/ Y}$ mice, identified dysregulation in the Ubiquinol-cytochrome c reductase core protein 1 (Uqcrc1) (Kriaucionis et al., 2006) and cardiolipin synthase 1 (Crls1) (Gold et al., 2014) genes encoding mitochondrial proteins. Uqcrc1 is a nuclear gene encoding a subunit of mitochondrial respiratory complex III and was found to be 
overexpressed in mice displaying overt neurological symptoms (P70) (Kriaucionis et al., 2006) whereas a downregulation of cardiolipin synthase 1 (Crls1) in symptomatic mice (12 weeks) compared to wild type mice was observed (Gold et al., 2014). Crls1 is involved in the synthesis of the mitochondrial-localised phospholipid cardiolipin (Schlame and Haldar, 1993) which is known to interact with various complexes of the respiratory chain and stabilize the higher order organization of the super-complexes (COI/III/IV and COII/III/IV) (Schagger, 2002).

\section{Synaptic function and neurotransmission:}

Prominent functional networks that are consistently altered in these studies relate to synaptic function and neurotransmission. Dysregulated genes involved in synaptic plasticity and function, neuronal migration, synaptic transmission, learning and behaviour modulation, and hippocampal dendrite development were reported in the cerebellum of male Mecp $2^{\mathrm{tm} 1.1 \mathrm{Jae} / \mathrm{Y}}$ and Mecp2 $2^{\mathrm{tm} 1.1 \mathrm{Bird} / \mathrm{Y}}$ mice (Jordan et al., 2007). Genes enriched in cellular adhesion and communication were found to be perturbed in a number of different neuronal cell types isolated from male Mecp $2^{-/ Y}$ mice (Sugino et al., 2014) and later confirmed by Ehrhart et al whose data was generated by reanalysing the data from Sugino et al (Ehrhart et al., 2016). Ehrhart et al also highlighted dysregulated genes involved in neuronal connectivity and communication particularly synaptic function, glutamate and glutathione metabolism as well as abnormal neuronal excitatory and inhibitory activity (Ehrhart et al., 2016). Differentially regulated genes including several immediate early and late response genes that are induced by neuronal activity and modulate signalling pathways associated with synaptic plasticity were also reported in excitatory and inhibitory 


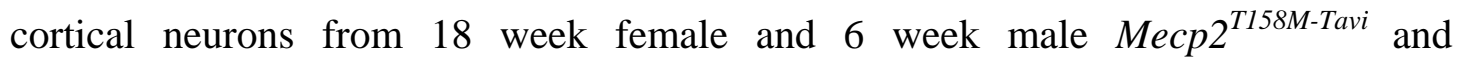
Mecp $2^{\text {R106W Tavi }}$ mice (Johnson et al., 2017).

\section{Cortex development and maturation:}

Genes involved in the development and maturation of the cortex were also found to be dysregulated. Specifically genes involved in ionic channels, glutamatergic receptors, cerebral cortex development and pathways delaying the maturation of the cortex were identified in embryonic cortical neurons from female Mecp2-null mice (Bedogni et al., 2016).

\section{Glial cells:}

Although MECP2 is expressed in a wide range of tissues, Rett syndrome is principally caused by the deficiency of MeCP2 in the cells of the brain (Chen et al., 2001) and thus apart from four studies (Gold et al., 2014, Hara et al., 2015, Orlic-Milacic et al., 2014, Sanfeliu et al., 2019), all transcriptional murine studies were confined to the brain. A handful of studies focused on the transcriptome of the whole brain (Guo et al., 2014, Kriaucionis et al., 2006, Nuber et al., 2005) however these studies revealed only subtle changes in gene expression which can be attributed to the brain being a heterogeneous organ consisting of many distinct functional regions that may individually be affected by the lack of Mecp2. As such, profiling studies of discrete regions of the brain and subtypes of neurons have ensued, uncovering more dramatic gene effects resulting from the loss of Mecp2, and overcoming the dilution issue associated with assaying complex tissues. Although the Rett phenotype is predominantly due to neuronal Mecp2 deficiency, astrocytes and microglia play a significant role in the pathogenesis of Rett syndrome (Sharma et al., 2018). Transcriptomic profiling of astrocytes cultured from early post-natal pups identified 
differentially expressed genes enriched in astrocyte signalling, neuronal support and function (Yasui et al., 2013), as well as glutamate receptor signalling and cytokine signalling (Delepine et al., 2015). In addition, microglia cultured from whole brains of female heterozygous Mecp2-null mice at 5 weeks old with no phenotypic symptoms, and 24 weeks with apparent phenotypic symptoms, revealed many dysregulated genes involved in the activation of macrophages, heat shock protein family genes and genes

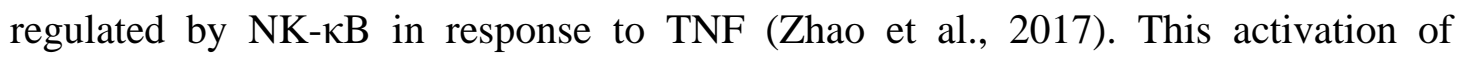
microglia was supported by another study which showed increased expression of TNF as well as glucocorticoid and hypoxia induced gene transcripts (Cronk et al., 2015).

\section{MECP2 overexpression:}

The overexpression of $M E C P 2$ is the cause of a clinically recognizable disorder that leads to a severe phenotype of intellectual disability and autistic features in males (Ramocki et al., 2010, Van Esch, 2012). Hence there has been considerable interest in understanding the effects of $M E C P 2$ overexpression and its genotype-phenotype correlation. Our search identified four transcriptomic studies that investigated the overexpression of Mecp2 in mice, two in the hypothalamus (Chahrour et al., 2008, Chen et al., 2015), one in the cerebellum (Ben-Shachar et al., 2009), and one in the amygdala (Samaco et al., 2012). These studies demonstrated that overexpression of Mecp2 leads to an increased expression of many genes, thus supporting the role of MECP2 as a transcription activator. Of interest, the Fatty acid binding protein 7 (Fabp7) gene was found to be upregulated in the overexpression mice in three of these studies (Ben-Shachar et al., 2009, Chahrour et al., 2008, Samaco et al., 2012) with Chen et al not recording the expression. FABP7 is a brain specific fatty acid binding protein part of the fatty acid binding proteins (FABPs) family which are 
small, highly conserved, cytoplasmic proteins that bind long-chain fatty acids and other hydrophobic ligands. FABP7 is expressed during development in radial glia, progenitor cells that are responsible for producing all of the neurons in the cerebral cortex.

The reciprocal relationship between differentially expressed genes in the knockout mouse studies and the overexpression mouse studies is of great interest as those genes that are dysregulated in both studies may be valid target genes of interest and worthy of further scrutiny. In order to shed further light on the molecular functions of MeCP2, these studies also compared the gene expression profiles of both overexpressing mice and knockout mice to tease out dysregulated genes resulting from loss or gain of MeCP2 expression. Within each study, the authors found a number of common genes that were upregulated in the overexpressing mice and downregulated in the knockout mice, supporting the role for MeCP2 as a modulator that can both increase and decrease gene expression. Of interest, in these comparisons, Fabp7 was upregulated in the overexpression mice but also downregulated in the knockout mice (Ben-Shachar et al., 2009, Chahrour et al., 2008, Samaco et al., 2012). Together with supporting evidence of Fabp7 being downregulated in a number of the other knockout studies (Pacheco et al., 2017, Urdinguio et al., 2008, Zhao et al., 2013) strongly suggests that Fabp7 could be a valid target gene of interest.

\section{Proteomic studies:}

Proteomic studies are a powerful approach to study disease in that they reveal changes in protein regulation during the progression of disease. Validating transcriptomic with proteomic data can be extremely powerful, but technically challenging. Most genome- 
wide expression studies on mouse models of Rett syndrome lack integration of multiomics datasets with one exception by Pacheco et al., who compared the transcriptome and proteome of symptomatic Mecp2-null male mice brain samples (Pacheco et al., 2017). This study identified 35 gene-protein matches with significant expression changes. One of these was FKBP Prolyl Isomerase 5 (FKBP5), a gene implicated in human stress and mood disorders through its actions in modulating glucocorticoid sensitivity (Klengel and Binder, 2015). The Fkbp5 gene was also found to be dysregulated in a number of transcriptomic studies (Ben-Shachar et al., 2009, Pacheco et al., 2017, Zhao et al., 2013) which suggests its potentially functional significance in Rett syndrome. Further, the study by Pacheco et al revealed a dysregulation in a number of signalling pathways and cellular networks including RNA metabolism, proteostasis, monoamine metabolism, and cholesterol synthesis in protein lysates from the whole cortex of symptomatic male Mecp2 $2^{\text {Jae/y }}$ mice at P60 (Pacheco et al., 2017). As this was the only study that conducted both transcriptomic and proteomic studies, the authors were able to find common 'hits' in both datasets, strengthening the analysis. Disrupted pathways associated with synaptic function and neurotransmission, neuronal morphology, and development were observed, indicating disturbed conduction and neuronal structure and organization. A disruption in glia markers such as myelination processes, astrocyte morphology, reactivation, and apoptosis were also observed. In addition the authors also observed a dysregulation in unique pathways associated with inflammation and the vasculature, cellular metabolism, calcium signalling, protein stability, DNA binding, and cytoskeletal cell structure (Pacheco et al., 2017). The study by Matarazzo and Ronnett, who studied protein expression in male Mecp2-null mice at 2 weeks and 4 weeks of age, also revealed aberrant protein expression enriched in cytoskeletal arrangement as well as 
in other biological functional networks such as chromatin modelling, energy metabolism, cell signalling, and neuroprotection (Matarazzo and Ronnett, 2004). In support of the transcriptomic studies, evidence of inflammation was observed by Cortelazzo et al, who demonstrated differentially expressed proteins involved in the acute phase response (APR) and inflammation in the plasma of symptomatic Mecp2 ${ }^{-}$ ${ }^{308}$ female mice (Cortelazzo et al., 2017).

\section{DISCUSSION}

The main aim of this review was to provide a summary of all the studies and highlight the reported dysregulated genes and functional pathways that are found to be perturbed in Rett syndrome mouse models. This data can be further analysed, using meta-analysis for the purpose of identifying new gene targets that may lead to therapeutics for the treatment of Rett syndrome or for unraveling novel biological insights that contribute to our understanding of the underlying pathophysiology of the disorder.

With the advent of new technologies such as RNA-seq, it is now possible to rapidly and effectively sequence and quantitate the gene expression of transcriptomes of interest in a way that has not been achieved before. However, despite this technology, the complete molecular picture for Rett syndrome is still unclear and by combining multiple omics studies, there is the potential to identify new pathways, reveal multigene interactions and establish the basis for disease progression.

Mouse models have been shown to recapitulate some of the features of the phenotype observed in patients (Calfa et al., 2011) and have provided a wealth of information on the underlying pathophysiology of the disorder. In addition to reproducing the genetic architecture of Rett syndrome in humans, a number of the biochemical abnormalities 
are also well represented in these mouse models (Deng et al., 2007). Despite considerable research in identifying the role of $M E C P 2$ and other Rett syndromeassociated genes (Ariani et al., 2008, Weaving et al., 2004) in the pathophysiology of the disease, there is still a lack of clarity in the factors leading to disease progression.

There has been considerable success in utilizing mouse models to develop therapeutic strategies for Rett syndrome. A number of promising clinical trials including insulinlike growth factor (IGF-1), sarizotan, trofinetide, glatiramer acetate, dextromethorphan, desipramine, fingolimod, triheptanoin, ketamine, and lovastatin have been produced from murine preclinical studies (Gold et al., 2018). However, to date, no therapeutic strategy has been translated into the clinic. This may not be due to the lack of efficacy of these treatments, but rather to the confounding and complex nature of the disorder and a general lack of a deep understanding of the functions of MeCP2. Patients display a broad range of phenotypic features, each manifesting at varying time points throughout development. Therefore, further scrutiny of the mouse model omic studies may uncover more information that could support future clinical trials. Although care must be taken when extrapolating the preclinical results to potential human clinical trials, studies in mouse models are critical for identifying convergent molecular pathways in Rett syndrome.

In this review, we have identified published transcriptomic and proteomic studies conducted on Rett syndrome mouse models and highlighted the signalling pathways and cellular networks that were identified to be aberrantly regulated. Although many genes have been investigated for their involvement in the pathogenesis of the disorder, a set of commonly dysregulated genes has yet to be identified across all (or most) studies. This may be achieved using meta-analysis, however, caution should be 
exercised and careful consideration needs to be taken with the design of the analysis. One of the confounding factors that may result in a lack of concordant dysregulated genes between studies, amongst others, is the heterogeneous cell populations of the brain which may dilute the effect of Mecp2-deficiency. As gene expression profiles can vary significantly between different cell types, this could result in failure to identify a common list of differentially expressed genes. In addition, the subtle changes in the differential expression of many genes could contribute to the diversity of gene expression encountered, yet may miss being detected by transcriptomic and proteomic analysis because the expression differences were too subtle. The variations in mouse models, age and sex of the mice used could also contribute to discordant results between studies. This is highlighted by the transcriptomic study by Jordan et al., who compared the Mecp $2^{\text {tm1.1Jae }}$ and Mecp $2^{\text {tm1.1Bird }}$ mouse models at three different disease progression stages using the same transcriptomic platform, yet they were unable to find more than a handful of commonly differentially expressed genes between the models (Jordan et al., 2007).

\section{Limitations:}

A major limitation of conducting transcriptomic studies of whole brains or selected brain regions is the heterogeneous cell population consisting of many different cell types including a variety of neuronal cells, microglia, astrocytes and oligodendrocytes as well as endothelial and fibroblast cells. It is widely accepted that different cell types confer different gene expressions and thus it is expected that the gene expression profiles will differ considerably among this heterogeneous cell population. Further, isolating specific brain regions of interest, especially small regions such as the hippocampus, is technically challenging, and therefore, the differentially 
expressed genes may be representative of the surrounding cells and not only of that particular region. Another limitation is that some samples may be pooled to meet the large RNA requirements for expression profiling. In this case, we should consider the possible effects of inter-mouse variation, where the gene expression of individual mice are so different that they dilute out any significant values.

Cultured cells also pose a limitation in that they no longer display the inherent phenotype and thus gene expression profiles that they would in situ. Microglia are particularly sensitive, as there are no in vitro methods that recapitulates all characteristics of adult homeostatic glia (Timmerman et al., 2018). Data showing that RNA transcript profiles of ex vivo microglia differ considerably from those of in vitro microglia which has, to a certain degree, been attributed to culturing in the presence of serum (Bohlen et al., 2017).

Differences in study design and utilizing different measurement platforms is a major issue, introducing platform based inconsistencies, making it difficult to conduct meaningful and accurate comparisons between studies. Other inherent problems that introduce study bias include small sample size, different statistical cut-offs (p-value and fold-change), genetic background of transgenic mouse models, animal environment, data quality, statistical power, different mouse models, ages, sex and anatomical regions studied. Lastly, despite Rett syndrome being a predominantly female-based disorder, the majority of these studies in this meta-analysis used male mice. Sexual dimorphism has been recognised as a major potential confounder in mouse studies (Karp et al., 2017).

This article is protected by copyright. All rights reserved. 


\section{Future directions:}

Despite all these studies, no meta-analysis has been conducted using the raw data in an attempt to tease out any converging genes or signalling pathways with the idea of identifying novel curative treatments for Rett syndrome. There may be a number of reasons for this, which include, but not limited to, the raw data of some of the studies not being publically accessible. Moving forward, raw data from every study should be deposited in publically accessible online repositories where meta-analysis, using standardised analysis approaches, may be conducted. As such, statistical parameters such as p-values, corrections for multiple testing, sample pooling and in the case of RNA-seq read-depth, read length and single/paired end reads, may be applied universally across all data sets. Furthermore combining transcriptomics with proteomics will enrich the investigations which may provide more reliable ‘druggable’ targets.

\section{Conclusion}

The importance of omics studies in driving discoveries in human genetics, especially in a complex neurodevelopmental disorder such as Rett syndrome is undeniable. The data generated from genome-wide studies supported by proteomics will systematically build an improved understanding of the key biological aberrations associated with MECP2 deficiency. We cannot also exclude the possibility of identification of "false positives" and inconclusive "leads" while we search for answers, however some of these leads may indeed open new avenues of research, bridging the gap between the known and the unknown. As a resource to quickly and comprehensively identify transcriptomic studies conducted in mouse models in Rett 
syndrome, we hope this review will assist researchers working towards tackling this devastating disorder.

\section{ACKNOWLEDGEMENTS:}

This work was supported by the Rett Syndrome Association of Australia and the International Rett Syndrome Foundation. The research conducted at the Murdoch Children's Research Institute was supported by the Victorian Government's Operational Infrastructure Support Program. The authors declare that there are no commercial or other conflicts of interest in connection with this research.

\section{REFERENCES:}

AMIR, R. E., VAN DEN VEYVER, I. B., WAN, M., TRAN, C. Q., FRANCKE, U. \& ZOGHBI, H. Y. 1999. Rett syndrome is caused by mutations in X-linked MECP2, encoding methyl-CpG-binding protein 2. Nat Genet, 23, 185-8.

ARIANI, F., HAYEK, G., RONDINELLA, D., ARTUSO, R., MENCARELLI, M. A., SPANHOLROSSETO, A., POLLAZZON, M., BUONI, S., SPIGA, O., RICCIARDI, S., MELONI, I., LONGO, I., MARI, F., BROCCOLI, V., ZAPPELLA, M. \& RENIERI, A. 2008. FOXG1 is responsible for the congenital variant of Rett syndrome. Am J Hum Genet, $83,89-93$.

ARMANI, R., ARCHER, H., CLARKE, A., VASUDEVAN, P., ZWEIER, C., HO, G., WILLIAMSON, S., CLOOSTERMAN, D., YANG, N. \& CHRISTODOULOU, J. 2012. Transcription factor 4 and myocyte enhancer factor $2 \mathrm{C}$ mutations are not common causes of Rett syndrome. Am J Med Genet A, 158A, 713-9.

BAKER, S. A., CHEN, L., WILKINS, A. D., YU, P., LICHTARGE, O. \& ZOGHBI, H. Y. 2013. An AT-hook domain in MeCP2 determines the clinical course of Rett syndrome and related disorders. Cell, 152, 984-96.

BEDOGNI, F., COBOLLI GIGLI, C., POZZI, D., ROSSI, R. L., SCARAMUZZA, L., ROSSETTI, G., PAGANI, M., KILSTRUP-NIELSEN, C., MATTEOLI, M. \& LANDSBERGER, N. 2016. Defects During Mecp2 Null Embryonic Cortex Development Precede the Onset of Overt Neurological Symptoms. Cereb Cortex, 26, 2517-2529.

BEN-SHACHAR, S., CHAHROUR, M., THALLER, C., SHAW, C. A. \& ZOGHBI, H. Y. 2009. Mouse models of MeCP2 disorders share gene expression changes in the cerebellum and hypothalamus. Hum Mol Genet, 18, 2431-42.

This article is protected by copyright. All rights reserved. 
BOHLEN, C. J., BENNETT, F. C., TUCKER, A. F., COLLINS, H. Y., MULINYAWE, S. B. \& BARRES, B. A. 2017. Diverse Requirements for Microglial Survival, Specification, and Function Revealed by Defined-Medium Cultures. Neuron, 94, 759-773 e8.

CALFA, G., PERCY, A. K. \& POZZO-MILLER, L. 2011. Experimental models of Rett syndrome based on Mecp2 dysfunction. Exp Biol Med (Maywood), 236, 3-19.

CHAHROUR, M., SUNG, Y. J., SHAW, C., ZHOU, X., WONG, S. T. C., QIN, J. \& ZOGHBI, H. Y. 2008. MeCP2, a key contributor to neurological disease, activates and represses transcription. Science, 320, 1224-1229.

CHEN, L., CHEN, K., LAVERY, L. A., BAKER, S. A., SHAW, C. A., LI, W. \& ZOGHBI, H. Y. 2015. MeCP2 binds to non-CG methylated DNA as neurons mature, influencing transcription and the timing of onset for Rett syndrome. Proc Natl Acad Sci U S A, 112, 5509-14.

CHEN, R. Z., AKBARIAN, S., TUDOR, M. \& JAENISCH, R. 2001. Deficiency of methylCpG binding protein-2 in CNS neurons results in a Rett-like phenotype in mice. Nat Genet, 27, 327-31.

CHEN, Y. J., SHIN, B. C., THAMOTHARAN, S. \& DEVASKAR, S. U. 2013. Creb1-Mecp2(m)CpG Complex Transactivates Postnatal Murine Neuronal Glucose Transporter Isoform 3 Expression. Endocrinology, 154, 1598-1611.

CHENG, T. L., WANG, Z. Z., LIAO, Q. M., ZHU, Y., ZHOU, W. H., XU, W. Q. \& QIU, Z. L. 2014. MeCP2 Suppresses Nuclear MicroRNA Processing and Dendritic Growth by Regulating the DGCR8/Drosha Complex. Developmental Cell, 28, 547-560.

CORTELAZZO, A., DE FELICE, C., DE FILIPPIS, B., RICCERI, L., LAVIOLA, G., LEONCINI, S., SIGNORINI, C., PESCAGLINI, M., GUERRANTI, R., TIMPERIO, A. M., ZOLLA, L., CICCOLI, L. \& HAYEK, J. 2017. Persistent Unresolved Inflammation in the Mecp2-308 Female Mutated Mouse Model of Rett Syndrome. Mediators Inflamm, 2017, 9467819.

CRONK, J. C., DERECKI, N. C., JI, E., XU, Y., LAMPANO, A. E., SMIRNOV, I., BAKER, W., NORRIS, G. T., MARIN, I., CODDINGTON, N., WOLF, Y., TURNER, S. D., ADEREM, A., KLIBANOV, A. L., HARRIS, T. H., JUNG, S., LITVAK, V. \& KIPNIS, J. 2015. Methyl-CpG Binding Protein 2 Regulates Microglia and Macrophage Gene Expression in Response to Inflammatory Stimuli. Immunity, 42, 679-91.

DELEPINE, C., NECTOUX, J., LETOURNEUR, F., BAUD, V., CHELLY, J., BILLUART, P. \& BIENVENU, T. 2015. Astrocyte Transcriptome from the Mecp2(308)Truncated Mouse Model of Rett Syndrome. Neuromolecular Med, 17, 353-63.

DENG, V., MATAGNE, V., BANINE, F., FRERKING, M., OHLIGER, P., BUDDEN, S., PEVSNER, J., DISSEN, G. A., SHERMAN, L. S. \& OJEDA, S. R. 2007. FXYD1 is an MeCP2 target gene overexpressed in the brains of Rett syndrome patients and Mecp2-null mice. Hum Mol Genet, 16, 640-50.

This article is protected by copyright. All rights reserved. 
EHRHART, F., COORT, S. L., CIRILLO, E., SMEETS, E., EVELO, C. T. \& CURFS, L. 2016. New insights in Rett syndrome using pathway analysis for transcriptomics data. Wien Med Wochenschr, 166, 346-52.

ELLAWAY, C. \& CHRISTODOULOU, J. 2001. Rett syndrome: clinical characteristics and recent genetic advances. Disabil Rehabil, 23, 98-106.

EVANS, J. C., ARCHER, H. L., COLLEY, J. P., RAVN, K., NIELSEN, J. B., KERR, A., WILLIAMS, E., CHRISTODOULOU, J., GECZ, J., JARDINE, P. E., WRIGHT, M. J., PILZ, D. T., LAZAROU, L., COOPER, D. N., SAMPSON, J. R., BUTLER, R., WHATLEY, S. D. \& CLARKE, A. J. 2005. Early onset seizures and Rett-like features associated with mutations in CDKL5. Eur J Hum Genet, 13, 1113-20.

GABEL, H. W., KINDE, B., STROUD, H., GILBERT, C. S., HARMIN, D. A., KASTAN, N. R., HEMBERG, M., EBERT, D. H. \& GREENBERG, M. E. 2015. Disruption of DNAmethylation-dependent long gene repression in Rett syndrome. Nature, 522, 89-93.

GOLD, W. A., KRISHNARAJY, R., ELLAWAY, C. \& CHRISTODOULOU, J. 2018. Rett Syndrome: A Genetic Update and Clinical Review Focusing on Comorbidities. ACS Chem Neurosci, 9, 167-176.

GOLD, W. A., WILLIAMSON, S. L., KAUR, S., HARGREAVES, I. P., LAND, J. M., PELKA, G. J., TAM, P. P. \& CHRISTODOULOU, J. 2014. Mitochondrial dysfunction in the skeletal muscle of a mouse model of Rett syndrome (RTT): implications for the disease phenotype. Mitochondrion, 15, 10-7.

GUO, W., TSUJIMURA, K., OTSUKA, I. M., IRIE, K., IGARASHI, K., NAKASHIMA, K. \& ZHAO, X. 2014. VPA alleviates neurological deficits and restores gene expression in a mouse model of Rett syndrome. PLoS One, 9, e100215.

GUTIERREZ, H. \& DAVIES, A. M. 2011. Regulation of neural process growth, elaboration and structural plasticity by NF-kappaB. Trends Neurosci, 34, 31625 .

HARA, M., TAKAHASHI, T., MITSUMASU, C., IGATA, S., TAKANO, M., MINAMI, T., YASUKAWA, H., OKAYAMA, S., NAKAMURA, K., OKABE, Y., TANAKA, E., TAKEMURA, G., KOSAI, K., YAMASHITA, Y. \& MATSUISHI, T. 2015. Disturbance of cardiac gene expression and cardiomyocyte structure predisposes Mecp2null mice to arrhythmias. Sci Rep, 5, 11204.

JANSSENS, S. \& BEYAERT, R. 2003. Functional diversity and regulation of different interleukin-1 receptor-associated kinase (IRAK) family members. Mol Cell, 11, 293-302.

JOHNSON, B. S., ZHAO, Y. T., FASOLINO, M., LAMONICA, J. M., KIM, Y. J., GEORGAKILAS, G., WOOD, K. H., BU, D., CUI, Y., GOFFIN, D., VAHEDI, G., KIM, T. H. \& ZHOU, Z. 2017. Biotin tagging of MeCP2 in mice reveals contextual insights into the Rett syndrome transcriptome. Nat Med, 23, 1203-1214.

This article is protected by copyright. All rights reserved. 
JONES, P. L., VEENSTRA, G. J., WADE, P. A., VERMAAK, D., KASS, S. U., LANDSBERGER, N., STROUBOULIS, J. \& WOLFFE, A. P. 1998. Methylated DNA and MeCP2 recruit histone deacetylase to repress transcription. Nat Genet, 19, 187-91.

JORDAN, C., LI, H. H., KWAN, H. C. \& FRANCKE, U. 2007. Cerebellar gene expression profiles of mouse models for Rett syndrome reveal novel MeCP2 targets. BMC Med Genet, 8, 36.

KARP, N. A., HELLER, R., YAACOBY, S., WHITE, J. K. \& BENJAMINI, Y. 2017. Improving the Identification of Phenotypic Abnormalities and Sexual Dimorphism in Mice When Studying Rare Event Categorical Characteristics. Genetics, 205, 491-501.

KISHI, N., MACDONALD, J. L., YE, J., MOLYNEAUX, B. J., AZIM, E. \& MACKLIS, J. D. 2016. Reduction of aberrant NF-kappaB signalling ameliorates Rett syndrome phenotypes in Mecp2-null mice. Nat Commun, 7, 10520.

KLENGEL, T. \& BINDER, E. B. 2015. FKBP5 allele-specific epigenetic modification in gene by environment interaction. Neuropsychopharmacology, 40, 244-6.

KRIAUCIONIS, S. \& BIRD, A. 2004. The major form of MeCP2 has a novel N-terminus generated by alternative splicing. Nucleic Acids Res, 32, 1818-23.

KRIAUCIONIS, S., PATERSON, A., CURTIS, J., GUY, J., MACLEOD, N. \& BIRD, A. 2006. Gene expression analysis exposes mitochondrial abnormalities in a mouse model of Rett syndrome. Mol Cell Biol, 26, 5033-42.

KRISHNARAJ, R., HO, G. \& CHRISTODOULOU, J. 2017. RettBASE: Rett syndrome database update. Hum Mutat, 38, 922-931.

LEWIS, J. D., MEEHAN, R. R., HENZEL, W. J., MAURER-FOGY, I., JEPPESEN, P., KLEIN, F. \& BIRD, A. 1992. Purification, sequence, and cellular localization of a novel chromosomal protein that binds to methylated DNA. Cell, 69, 905-14.

LIYANAGE, V. R. \& RASTEGAR, M. 2014. Rett syndrome and MeCP2. Neuromolecular Med, 16, 231-64.

MATARAZZO, V. \& RONNETT, G. V. 2004. Temporal and regional differences in the olfactory proteome as a consequence of MeCP2 deficiency. Proc Natl Acad Sci U S A, 101, 7763-8.

MCGRAW, C. M., SAMACO, R. C. \& ZOGHBI, H. Y. 2011. Adult neural function requires MeCP2. Science, 333, 186.

MELLEN, M., AYATA, P., DEWELL, S., KRIAUCIONIS, S. \& HEINTZ, N. 2012. MeCP2 binds to $5 \mathrm{hmC}$ enriched within active genes and accessible chromatin in the nervous system. Cell, 151, 1417-30.

This article is protected by copyright. All rights reserved. 
MELLEN, M., AYATA, P. \& HEINTZ, N. 2017. 5-hydroxymethylcytosine accumulation in postmitotic neurons results in functional demethylation of expressed genes. Proc Natl Acad Sci U S A, 114, E7812-E7821.

MNATZAKANIAN, G. N., LOHI, H., MUNTEANU, I., ALFRED, S. E., YAMADA, T., MACLEOD, P. J., JONES, J. R., SCHERER, S. W., SCHANEN, N. C., FRIEZ, M. J., VINCENT, J. B. \& MINASSIAN, B. A. 2004. A previously unidentified MECP2 open reading frame defines a new protein isoform relevant to Rett syndrome. Nat Genet, 36, 339-41.

NAN, X., NG, H. H., JOHNSON, C. A., LAHERTY, C. D., TURNER, B. M., EISENMAN, R. N. \& BIRD, A. 1998. Transcriptional repression by the methyl-CpG-binding protein MeCP2 involves a histone deacetylase complex. Nature, 393, 386-9.

NEUL, J. L., KAUFMANN, W. E., GLAZE, D. G., CHRISTODOULOU, J., CLARKE, A. J., BAHI-BUISSON, N., LEONARD, H., BAILEY, M. E., SCHANEN, N. C., ZAPPELLA, M., RENIERI, A., HUPPKE, P., PERCY, A. K. \& RETTSEARCH, C. 2010. Rett syndrome: revised diagnostic criteria and nomenclature. Ann Neurol, 68, 94450.

NUBER, U. A., KRIAUCIONIS, S., ROLOFF, T. C., GUY, J., SELFRIDGE, J., STEINHOFF, C., SCHULZ, R., LIPKOWITZ, B., ROPERS, H. H., HOLMES, M. C. \& BIRD, A. 2005. Up-regulation of glucocorticoid-regulated genes in a mouse model of Rett syndrome. Hum Mol Genet, 14, 2247-56.

ORLIC-MILACIC, M., KAUFMAN, L., MIKHAILOV, A., CHEUNG, A. Y., MAHMOOD, H., ELLIS, J., GIANAKOPOULOS, P. J., MINASSIAN, B. A. \& VINCENT, J. B. 2014. Over-expression of either MECP2_e1 or MECP2_e2 in neuronally differentiated cells results in different patterns of gene expression. PLoS One, 9, e91742.

PACHECO, N. L., HEAVEN, M. R., HOLT, L. M., CROSSMAN, D. K., BOGGIO, K. J., SHAFFER, S. A., FLINT, D. L. \& OLSEN, M. L. 2017. RNA sequencing and proteomics approaches reveal novel deficits in the cortex of Mecp2-deficient mice, a model for Rett syndrome. Mol Autism, 8, 56.

PHILIPPE, C., AMSALLEM, D., FRANCANNET, C., LAMBERT, L., SAUNIER, A., VERNEAU, F. \& JONVEAUX, P. 2010. Phenotypic variability in Rett syndrome associated with FOXG1 mutations in females. J Med Genet, 47, 59-65.

RAMAN, A. T., POHODICH, A. E., WAN, Y. W., YALAMANCHILI, H. K., LOWRY, W. E., ZOGHBI, H. Y. \& LIU, Z. 2018. Apparent bias toward long gene misregulation in MeCP2 syndromes disappears after controlling for baseline variations. Nat Commun, 9, 3225.

RAMOCKI, M. B., TAVYEV, Y. J. \& PETERS, S. U. 2010. The MECP2 duplication syndrome. Am J Med Genet A, 152A, 1079-88.

This article is protected by copyright. All rights reserved. 
RENTHAL, W., BOXER, L. D., HRVATIN, S., LI, E., SILBERFELD, A., NAGY, M. A., GRIFFITH, E. C., VIERBUCHEN, T. \& GREENBERG, M. E. 2018. Characterization of human mosaic Rett syndrome brain tissue by single-nucleus RNA sequencing. Nat Neurosci, 21, 1670-1679.

SAMACO, R. C., MANDEL-BREHM, C., MCGRAW, C. M., SHAW, C. A., MCGILL, B. E. \& ZOGHBI, H. Y. 2012. Crh and Oprm1 mediate anxiety-related behavior and social approach in a mouse model of MECP2 duplication syndrome. Nat Genet, 44, 206-11.

SANFELIU, A., HOKAMP, K., GILL, M. \& TROPEA, D. 2019. Transcriptomic Analysis of Mecp2 Mutant Mice Reveals Differentially Expressed Genes and Altered Mechanisms in Both Blood and Brain. Front Psychiatry, 10, 278.

SCHAGGER, H. 2002. Respiratory chain supercomplexes of mitochondria and bacteria. Biochim Biophys Acta, 1555, 154-9.

SCHLAME, M. \& HALDAR, D. 1993. Cardiolipin is synthesized on the matrix side of the inner membrane in rat liver mitochondria. J Biol Chem, 268, 74-9.

SHARMA, K., SINGH, J., FROST, E. E. \& PILLAI, P. P. 2018. MeCP2 in central nervous system glial cells: current updates. Acta Neurobiol Exp (Wars), 78, 30-40.

SHOVLIN, S. \& TROPEA, D. 2018. Transcriptome level analysis in Rett syndrome using human samples from different tissues. Orphanet J Rare Dis, 13, 113.

SHULYAKOVA, N., ANDREAZZA, A. C., MILLS, L. R. \& EUBANKS, J. H. 2017. Mitochondrial Dysfunction in the Pathogenesis of Rett Syndrome: Implications for Mitochondria-Targeted Therapies. Front Cell Neurosci, 11, 58.

SMRT, R. D., EAVES-EGENES, J., BARKHO, B. Z., SANTISTEVAN, N. J., ZHAO, C., AIMONE, J. B., GAGE, F. H. \& ZHAO, X. 2007. Mecp2 deficiency leads to delayed maturation and altered gene expression in hippocampal neurons. Neurobiol Dis, 27, 77-89.

SUGINO, K., HEMPEL, C. M., OKATY, B. W., ARNSON, H. A., KATO, S., DANI, V. S. \& NELSON, S. B. 2014. Cell-type-specific repression by methyl-CpG-binding protein 2 is biased toward long genes. Journal of Neuroscience, 34, 12877-83.

TIMMERMAN, R., BURM, S. M. \& BAJRAMOVIC, J. J. 2018. An Overview of in vitro Methods to Study Microglia. Front Cell Neurosci, 12, 242.

TUDOR, M., AKBARIAN, S., CHEN, R. Z. \& JAENISCH, R. 2002. Transcriptional profiling of a mouse model for Rett syndrome reveals subtle transcriptional changes in the brain. Proc Natl Acad Sci U S A, 99, 15536-41.

URDINGUIO, R. G., LOPEZ-SERRA, L., LOPEZ-NIEVA, P., ALAMINOS, M., DIAZ-URIARTE, R., FERNANDEZ, A. F. \& ESTELLER, M. 2008. Mecp2-null mice provide new neuronal targets for Rett syndrome. PLoS One, 3, e3669.

This article is protected by copyright. All rights reserved. 
VACCA, M., TRIPATHI, K. P., SPERANZA, L., AIESE CIGLIANO, R., SCALABRI, F., MARRACINO, F., MADONNA, M., SANSEVERINO, W., PERRONE-CAPANO, C., GUARRACINO, M. R. \& D'ESPOSITO, M. 2016. Effects of Mecp2 loss of function in embryonic cortical neurons: a bioinformatics strategy to sort out non-neuronal cells variability from transcriptome profiling. $B M C$ Bioinformatics, 17 Suppl 2, 14.

VAN ESCH, H. 2012. MECP2 Duplication Syndrome. Mol Syndromol, 2, 128-136.

WEAVING, L. S., CHRISTODOULOU, J., WILLIAMSON, S. L., FRIEND, K. L., MCKENZIE, O. L., ARCHER, H., EVANS, J., CLARKE, A., PELKA, G. J., TAM, P. P., WATSON, C., LAHOOTI, H., ELLAWAY, C. J., BENNETTS, B., LEONARD, H. \& GECZ, J. 2004. Mutations of CDKL5 cause a severe neurodevelopmental disorder with infantile spasms and mental retardation. Am J Hum Genet, 75, 1079-93.

YASUI, D. H., XU, H., DUNAWAY, K. W., LASALLE, J. M., JIN, L. W. \& MAEZAWA, I. 2013. MeCP2 modulates gene expression pathways in astrocytes. Mol Autism, 4, 3.

ZHAO, D., MOKHTARI, R., PEDROSA, E., BIRNBAUM, R., ZHENG, D. \& LACHMAN, H. M. 2017. Transcriptome analysis of microglia in a mouse model of Rett syndrome: differential expression of genes associated with microglia/macrophage activation and cellular stress. Mol Autism, 8, 17.

ZHAO, Y. T., GOFFIN, D., JOHNSON, B. S. \& ZHOU, Z. 2013. Loss of MeCP2 function is associated with distinct gene expression changes in the striatum. Neurobiol Dis, 59, 257-66.

This article is protected by copyright. All rights reserved. 
Table 1. Summary of transcriptomics and proteomics studies on samples from mice models associated with RTT

\begin{tabular}{|c|c|c|c|c|c|c|c|c|c|c|c|}
\hline $\begin{array}{l}\mathbf{N} \\
\mathbf{0}\end{array}$ & $\begin{array}{l}\text { Referen } \\
\text { ce }\end{array}$ & $\begin{array}{l}\mathbf{Y} \\
\mathbf{e} \\
\text { ar }\end{array}$ & $\begin{array}{l}\text { Transge } \\
\text { nic } \\
\text { Model }\end{array}$ & $\begin{array}{l}\text { Ge } \\
\text { nde } \\
\text { r }\end{array}$ & $\begin{array}{l}\text { Cell } \\
\text { source }\end{array}$ & $\begin{array}{l}\text { Age } \\
\text { when } \\
\text { studie } \\
\text { d }\end{array}$ & $\begin{array}{l}\text { No } \\
\text { of } \\
\text { sam } \\
\text { ples }\end{array}$ & $\begin{array}{l}\text { DE at } \\
\text { statistical } \\
\text { cut-off }\end{array}$ & IE & $\begin{array}{l}\mathbf{R} \\
\mathbf{E}\end{array}$ & $\begin{array}{l}\text { SGGNIFCANT } \\
\text { GENES }\end{array}$ \\
\hline 1 & $\begin{array}{l}\text { Tudoret } \\
\text { al. } \\
\text { PMID:12 } \\
432090\end{array}$ & $\begin{array}{l}20 \\
02\end{array}$ & $\begin{array}{l}\text { (a) } \\
\text { Mecp2 }{ }^{11} \\
\text { ox/Y } \\
\text { (b) } \\
\text { Mecp2- } \\
\text { conditio } \\
\text { nal } \\
\text { knockou } \\
t \\
\text { 129/SVJ } \\
\text { ae, } \\
\text { BALB/C, } \\
\text { C57BL/6 }\end{array}$ & $\begin{array}{l}\text { mal } \\
\mathrm{e}\end{array}$ & $\begin{array}{l}\text { forebrai } \\
\text { n, } \\
\text { cortex, } \\
\text { hippoc } \\
\text { ampus }\end{array}$ & $\begin{array}{l}\text { (a)P2 } \\
4, P 35, \\
\text { P56,P } \\
63 \\
\text { (b) } \\
\text { P135- } \\
\text { P180 }\end{array}$ & $\begin{array}{l}100 \\
\text { (tota } \\
\text { I) }\end{array}$ & \multicolumn{3}{|c|}{$\begin{array}{l}\text { No signific ant gene } \\
\text { expression changes } \\
\text { reported } \\
p<0.05\end{array}$} & \\
\hline 2 & $\begin{array}{l}\text { Nuber } \\
\text { et al. } \\
\text { PMID:16 } \\
002417\end{array}$ & $\begin{array}{l}20 \\
05\end{array}$ & $\begin{array}{l}\text { Mecp2- } \\
/ Y \\
\text { C57BL/6 } \\
J\end{array}$ & $\begin{array}{l}\mathrm{mal} \\
\mathrm{e}\end{array}$ & $\begin{array}{l}\text { whole } \\
\text { brain }\end{array}$ & P74 & 1 & $\begin{array}{l}11 \\
p<0.001\end{array}$ & 8 & 3 & SG K1,FKBP5 \\
\hline 3 & $\begin{array}{l}\text { Kriaucio } \\
\text { nis et al. } \\
\text { PMID:16 } \\
782889\end{array}$ & $\begin{array}{l}20 \\
06\end{array}$ & $\begin{array}{l}\text { Mecp2- } \\
\text { YY } \\
\text { C57BL/6 }\end{array}$ & $\begin{array}{l}\mathrm{mal} \\
\mathrm{e}\end{array}$ & $\begin{array}{l}\text { whole } \\
\text { brain }\end{array}$ & $\begin{array}{l}\text { P30, } \\
\text { P55, } \\
\text { P70 }\end{array}$ & 3 & $\begin{array}{l}12 \text { (at } \\
\text { P70) } \\
p<0.05\end{array}$ & 7 & 4 & $\begin{array}{l}\text { UQCRC } 1 \text {, } \\
\text { CDON }\end{array}$ \\
\hline 4 & $\begin{array}{l}\text { Jordan } \\
\text { et al. } \\
\text { PMID:17 } \\
584923\end{array}$ & $\begin{array}{l}20 \\
07\end{array}$ & $\begin{array}{l}\text { (a) } \\
\text { Mecp2t } \\
\text { m1.1jae/Y } \\
\text { (Mecp2- } \\
\text { mutant) } \\
\text { (b) } \\
\text { Mecp } 2^{\mathrm{t}} \\
\text { m1.1Bird/Y } \\
\text { BALB/CJ , } \\
\text { C57BL/6 } \\
\text { J }\end{array}$ & $\begin{array}{l}\mathrm{mal} \\
\mathrm{e}\end{array}$ & $\begin{array}{l}\text { cerebell } \\
\text { um }\end{array}$ & $\begin{array}{l}2,4,8 \\
\text { week } \\
\text { s }\end{array}$ & $>20$ & $\begin{array}{l}\text { (a) } 840 \text { ( } 8 \\
\text { weeks) } \\
\text { (b) } 849 \text { ( } 8 \\
\text { weeks) } \\
p<0.05\end{array}$ & $\begin{array}{l}441 \\
615\end{array}$ & $\begin{array}{l}3 \\
9 \\
9 \\
\\
2 \\
3 \\
4\end{array}$ & $\begin{array}{l}\text { IRAK1,MEG 3,F } \\
\text { XYD1,RELN }\end{array}$ \\
\hline
\end{tabular}

This article is protected by copyright. All rights reserved. 


\begin{tabular}{|c|c|c|c|c|c|c|c|c|c|c|c|}
\hline 5 & $\begin{array}{l}\text { Smrt et } \\
\text { al. } \\
\text { PMID:17 } \\
\text { 532643 }\end{array}$ & $\begin{array}{l}20 \\
07\end{array}$ & $\begin{array}{l}\begin{array}{l}\text { Mecp2t } \\
\text { m1.1.jae }\end{array} \\
\text { (Mecp2- } \\
\text { mutant) } \\
\text { ICR }\end{array}$ & $\begin{array}{l}\mathrm{mal} \\
\mathrm{e}\end{array}$ & $\begin{array}{l}\text { granule } \\
\text { cells of } \\
\text { dentate } \\
\text { gyrus } \\
\text { (hippoc } \\
\text { ampus) }\end{array}$ & $\begin{array}{l}8 \\
\text { week } \\
\text { s }\end{array}$ & 4 & $\begin{array}{l}13 \\
p<0.05\end{array}$ & 12 & 1 & $\begin{array}{l}\text { PFDN5. } \\
\text { UC HL1,SFXN3, } \\
\text { OSBPL9, } \\
\text { ZSC AN21,ARP } \\
\text { C3,SDC 2, } \\
\text { UQ CR10 } \\
\text { HMGB1 }\end{array}$ \\
\hline 6 & $\begin{array}{l}\text { Chahro } \\
\text { uret al. } \\
\text { PMID:18 } \\
511691\end{array}$ & $\begin{array}{l}20 \\
08\end{array}$ & $\begin{array}{l}\text { (a) } \\
\text { Mecp2- } \\
/ y \\
\text { (b) } \\
\text { MECP2- } \\
\text { Tg } \\
\text { (MECP2- } \\
\text { overexp } \\
\text { ressed) } \\
\text { C57BL } 6 \\
\text { J }\end{array}$ & $\begin{array}{l}\mathrm{mal} \\
\mathrm{e}\end{array}$ & $\begin{array}{l}\text { hypotha } \\
\text { lamus }\end{array}$ & $\begin{array}{l}6 \\
\text { week } \\
\text { s }\end{array}$ & 4 & $\begin{array}{l}\text { a) } 369(b) \\
1187 \ddagger \\
p<0.05\end{array}$ & $\begin{array}{l}85 \\
940\end{array}$ & $\begin{array}{l}2 \\
8 \\
4 \\
\\
2 \\
4 \\
7\end{array}$ & CREB1,BDNF \\
\hline 7 & $\begin{array}{l}\text { Urdingui } \\
\text { o et al. } \\
\text { PMID:18 } \\
989361\end{array}$ & $\begin{array}{l}20 \\
08\end{array}$ & $\begin{array}{l}\text { Mecp2- } \\
\text { iY } \\
\text { C57BL } 6 \\
J\end{array}$ & $\begin{array}{l}\mathrm{mal} \\
\mathrm{e}\end{array}$ & $\begin{array}{l}\text { cortex, } \\
\text { midbrai } \\
\text { n, } \\
\text { cerebell } \\
\text { um }\end{array}$ & $\begin{array}{l}\text { 6-10 } \\
\text { week } \\
\text { s }\end{array}$ & 4 & 53 & 29 & $\begin{array}{l}2 \\
4\end{array}$ & $\begin{array}{l}\text { FKBP5, MOBP, } \\
\text { PLAGL1, DDC, } \\
\text { MLT2H, EYA2, } \\
\text { AND S100A9 } \\
\text { IRAK1, PRODH } \\
\text { AND DLK1 }\end{array}$ \\
\hline 8 & $\begin{array}{l}\text { Ben- } \\
\text { Shacha } \\
\text { ret al. } \\
\text { PMID:19 } \\
369296\end{array}$ & $\begin{array}{l}20 \\
09\end{array}$ & $\begin{array}{l}\text { (a) } \\
\text { Mecp2- } \\
\text { /Y } \\
\text { (b) } \\
\text { MECP2- } \\
\text { Tg } \\
\text { (MECP2- } \\
\text { overexp } \\
\text { ressed) } \\
\text { C57BL/6 } \\
\text { J }\end{array}$ & $\begin{array}{l}\mathrm{mal} \\
\mathrm{e}\end{array}$ & $\begin{array}{l}\text { cerebell } \\
\text { um }\end{array}$ & $\begin{array}{l}6 \\
\text { week } \\
\text { s }\end{array}$ & 5 & $\begin{array}{l}\text { a) } 1102(b \\
\text { ) } 1180 \\
p<0.05\end{array}$ & $\begin{array}{l}286 \\
755\end{array}$ & $\begin{array}{l}8 \\
1 \\
6 \\
\\
4 \\
2 \\
5\end{array}$ & $\begin{array}{l}\text { PRLF2, RCOR2, } \\
\text { GPR26, LRP1B }\end{array}$ \\
\hline 9 & $\begin{array}{l}\text { Samac } \\
\text { o et al. } \\
\text { PMID: } \\
2223148 \\
1\end{array}$ & $\begin{array}{l}20 \\
12\end{array}$ & $\begin{array}{l}\text { a) } \\
\text { Mecp2- } \\
\text { /Y } \\
\text { (b) } \\
\text { MECP2- } \\
\text { Tg } \\
\text { (MECP2- } \\
\text { overexp } \\
\text { ressed) }\end{array}$ & $\begin{array}{l}\mathrm{mal} \\
\mathrm{e}\end{array}$ & $\begin{array}{l}\text { amygd } \\
\text { ala }\end{array}$ & $\begin{array}{l}6 \\
\text { week } \\
\text { s }\end{array}$ & 4 & $\begin{array}{l}1060 \\
\text { (genes } \\
\text { altered in } \\
\text { opposite } \\
\text { directions } \\
\text { in } \\
\text { Mecp2- } \\
\text { null and } \\
\text { Mecp2- } \\
\text { overexpr } \\
\text { esseds } \\
\text { FDR } \leq \\
0.05\end{array}$ & & & CRH, OPRMI \\
\hline
\end{tabular}

This article is protected by copyright. All rights reserved. 


\begin{tabular}{|c|c|c|c|c|c|c|c|c|c|c|c|}
\hline $\begin{array}{l}1 \\
0\end{array}$ & $\begin{array}{l}\text { Mellén } \\
\text { et al } \\
\text { PMID: } \\
2326013 \\
5\end{array}$ & $\begin{array}{l}20 \\
12\end{array}$ & $\begin{array}{l}\text { Mec } \\
\text { p2'm1. } \\
\text { 1Bird } \\
\text { C57BL/6 } \\
\text { J }\end{array}$ & $\begin{array}{l}\mathrm{mal} \\
\mathrm{e}\end{array}$ & $\begin{array}{l}\text { cerebell } \\
\text { um }\end{array}$ & $\begin{array}{l}7-11 \\
\text { week } \\
\text { s }\end{array}$ & 4 & & 37 & $\begin{array}{l}2 \\
6 \\
2\end{array}$ & $\begin{array}{l}\text { PRKAB1,CCD } \\
\text { C63,MYBPC } 3 \text {, } \\
\text { CPNE6,BMF }\end{array}$ \\
\hline 1 & $\begin{array}{l}\text { Baker } \\
\text { et al. } \\
\text { PMID:23 } \\
452848\end{array}$ & $\begin{array}{l}20 \\
13\end{array}$ & $\begin{array}{l}\text { Mecp2- } \\
\text { /Y } \\
\text { Mecp2 } \\
\text { R270X/Y } \\
\text { Mecp2 } \\
\text { G273X/Y; } \\
\text { F1 } \\
\text { PVB;129S } \\
\text { VEV }\end{array}$ & $\begin{array}{l}\mathrm{mal} \\
\mathrm{e}\end{array}$ & $\begin{array}{l}\text { hippoc } \\
\text { ampus }\end{array}$ & $\begin{array}{l}\text { (a) } 4 \\
\text { week } \\
\text { s } \\
\text { (b) } 9 \\
\text { week } \\
\text { s }\end{array}$ & 4 & $\begin{array}{l}\text { a) } 2778 \neq \text { ( } \\
\text { b) } 3082 \\
\text { p }<0.05\end{array}$ & $n / s$ & & $\begin{array}{l}\text { BDNF, SST, } \\
\text { TAK1, OPRK1 } \\
\text { MEF2C AND } \\
\text { GRIN2 }\end{array}$ \\
\hline $\begin{array}{l}1 \\
2\end{array}$ & $\begin{array}{l}\text { Yasui et } \\
\text { al. } \\
\text { PMID:23 } \\
351786\end{array}$ & $\begin{array}{l}20 \\
13\end{array}$ & $\begin{array}{l}\text { Mecp2- } \\
\text { null } \\
\text { C57BL/6 } \\
\text { J }\end{array}$ & $\mathrm{n} / \mathrm{s}$ & $\begin{array}{l}\text { astrocyt } \\
\text { e cells } \\
\text { from } \\
\text { cortex }\end{array}$ & $\begin{array}{l}\text { P1+ } \\
2-4 \\
\text { week } \\
\text { s } \\
\text { (DIV) }\end{array}$ & $n / s$ & $\begin{array}{l}118 \\
p<0.05\end{array}$ & 55 & $\begin{array}{l}6 \\
3\end{array}$ & $\begin{array}{l}\text { AARD1, } \\
\text { SLC 38A1 } \\
\text {,ARMC 3,CDO } \\
\text { N }\end{array}$ \\
\hline $\begin{array}{l}1 \\
3\end{array}$ & $\begin{array}{l}\text { Thao et } \\
\text { al. } \\
\text { PMID:23 } \\
948639\end{array}$ & $\begin{array}{l}20 \\
13\end{array}$ & $\begin{array}{l}\text { (a) } \\
\text { Mecp2- } \\
\text { nulll } \\
\text { (b) } \\
\text { Mecp221 } \\
\text { oxy; } \\
\text { Dlx5/6- } \\
\text { cre } \\
\text { C57BL/6 } \\
\text { J }\end{array}$ & $\begin{array}{l}\mathrm{mal} \\
\mathrm{e}\end{array}$ & striatum & $\begin{array}{l}\text { (a) } \\
\text { P60 } \\
\text { (b) } \\
\text { P7, } \\
\text { P90 }\end{array}$ & $\mathrm{n} / \mathrm{s}$ & $\begin{array}{l}\text { (a) } 127 \\
\text { (b) } 21 \text { (at } \\
\text { P90) } \\
\text { FDR } \leq \\
0.05\end{array}$ & $\begin{array}{l}68 \\
12\end{array}$ & $\begin{array}{l}5 \\
9 \\
9\end{array}$ & $\begin{array}{l}\text { EXPH5, } \\
\text { ROBO3, DRD3, } \\
\text { SATB1, } \\
\text { DSG 1C, AND } \\
\text { DLK1 }\end{array}$ \\
\hline 4 & $\begin{array}{l}\text { Gold et } \\
\text { al. } \\
\text { PMID:24 } \\
613463\end{array}$ & $\begin{array}{l}20 \\
14\end{array}$ & $\underset{\text { mecp } 2^{t}}{\operatorname{miTam}^{t}}$ & $\begin{array}{l}\mathrm{mal} \\
\mathrm{e}\end{array}$ & $\begin{array}{l}\text { skeletal } \\
\text { muscle }\end{array}$ & $\begin{array}{l}\text { (a) } 6 \\
\text { week } \\
\text { s } \\
\text { (b) } 12 \\
\text { week } \\
\text { s }\end{array}$ & 3 & $\begin{array}{l}\text { (a) } 23 \\
\text { (b) } 22 \\
p<0.05\end{array}$ & $\begin{array}{l}19 \\
14\end{array}$ & $\begin{array}{l}4 \\
8\end{array}$ & $\begin{array}{l}\text { CRLS1, } \\
\text { MTCO1, } \\
\text { CILP2, TINAG }\end{array}$ \\
\hline $\begin{array}{l}1 \\
5\end{array}$ & $\begin{array}{l}\text { Guo et } \\
\text { al. } \\
\text { PMID:24 } \\
968028\end{array}$ & $\begin{array}{l}20 \\
14\end{array}$ & $\begin{array}{l}\text { Mecp2t } \\
\text { m1.1.jae/Y } \\
\text { (Mecp2 } \\
\text { mutant) } \\
\text { + saline } \\
\text { ICR }\end{array}$ & $\begin{array}{l}\mathrm{mal} \\
\mathrm{e}\end{array}$ & $\begin{array}{l}\text { whole } \\
\text { brain }\end{array}$ & $\begin{array}{l}8 \\
\text { week } \\
\text { s }\end{array}$ & 3 & $>300$ & $n / s$ & & $\begin{array}{l}\text { CNTN1, } \\
\text { ZSSAN1, } \\
\text { FOXP1 }\end{array}$ \\
\hline
\end{tabular}

This article is protected by copyright. All rights reserved. 


\begin{tabular}{|c|c|c|c|c|c|c|c|c|c|c|c|}
\hline $\begin{array}{l}1 \\
6\end{array}$ & $\begin{array}{l}\text { Orlic- } \\
\text { Milacic } \\
\text { et al. } \\
\text { PMID:24 } \\
699272\end{array}$ & $\begin{array}{l}20 \\
14\end{array}$ & $\begin{array}{l}\text { (a) } \\
\text { Mecp2- } \\
\text { Y }+ \\
\text { MECP2_ } \\
\text { e1 } \\
\text { rescue } \\
\text { (b) } \\
\text { Mecp2- } \\
\text { ir+ } \\
\text { MECP2 } \\
\text { e2 } \\
\text { rescue }\end{array}$ & $\begin{array}{l}\mathrm{mal} \\
\mathrm{e}\end{array}$ & $\begin{array}{l}\text { fibroblas } \\
\text { ts }\end{array}$ & DIV7 & 3 & $\begin{array}{l}\text { Varies } \\
\text { between } \\
\text { transcript } \\
\mathrm{p}<0.05\end{array}$ & $\begin{array}{l}(a) \\
807 \\
\\
(b) \\
94\end{array}$ & $\begin{array}{l}\text { ( } \\
\mathrm{a} \\
) \\
2 \\
3 \\
6 \\
\\
( \\
\mathrm{b} \\
) \\
1 \\
4 \\
0\end{array}$ & $\begin{array}{l}\text { SRPX2, NAV3, } \\
\text { NPY1R, SYN3, } \\
\text { AND SEMA3D } \\
\\
\text { DOCK8, } \\
\text { GABRA2, } \\
\text { KCNA1, } \\
\text { FOXG 1,UNC5 } \\
\text { C AND RPH3A }\end{array}$ \\
\hline $\begin{array}{l}1 \\
7\end{array}$ & $\begin{array}{l}\text { Sugino } \\
\text { et al. } \\
\text { PMID:25 } \\
\text { 232122 }\end{array}$ & $\begin{array}{l}20 \\
14\end{array}$ & $\begin{array}{l}\text { Mecp2- } \\
\text { ir } \\
\text { C57BL/6 } \\
\text { J }\end{array}$ & $\mathrm{e}^{\mathrm{mal}}$ & $\begin{array}{l}4 \\
\text { distinct } \\
\text { neurona } \\
\text { Icell } \\
\text { types }\end{array}$ & $\begin{array}{l}\text { P37- } \\
\text { P55 } \\
\text { P22- } \\
\text { P25 }\end{array}$ & 3 & $\begin{array}{l}822 \\
Q<0.005\end{array}$ & 462 & $\begin{array}{l}3 \\
5 \\
0\end{array}$ & $\begin{array}{l}\text { CD99L2, } \\
\text { RAB39B }\end{array}$ \\
\hline $\begin{array}{l}1 \\
8\end{array}$ & $\begin{array}{l}\text { Chen } \\
\text { et al. } \\
\text { PMID:25 } \\
870282\end{array}$ & $\begin{array}{l}20 \\
15\end{array}$ & $\begin{array}{l}\text { (a) } \\
\text { Mec } \\
\text { p2 } \\
\text { 1Bird } \\
\\
\text { (b) } \\
\text { MECP2- } \\
\text { Tg } \\
\text { (MECP2- } \\
\text { overexp } \\
\text { ressed) }\end{array}$ & $\begin{array}{l}\mathrm{mal} \\
\mathrm{e}\end{array}$ & $\begin{array}{l}\text { hypotha } \\
\text { lamus }\end{array}$ & $\begin{array}{l}7 \\
\text { week } \\
\text { s }\end{array}$ & & $Q<0.005$ & & & \\
\hline $\begin{array}{l}1 \\
9\end{array}$ & $\begin{array}{l}\text { Cronk } \\
\text { et al. } \\
\text { PMID:25 } \\
\text { 902482 }\end{array}$ & $\begin{array}{l}20 \\
15\end{array}$ & $\begin{array}{l}\text { Mec } \\
\mathrm{p} 2^{\mathrm{Tm} 1} \\
\text { 1Bird } \\
\text { C57BL/6 } \\
\text { J }\end{array}$ & $n / s$ & $\begin{array}{l}\text { (a)micr } \\
\text { oglia (b) } \\
\text { pentone } \\
\text { al } \\
\text { macrop } \\
\text { hages }\end{array}$ & $n / s$ & $\begin{array}{l}\text { Vari } \\
\text { es } \\
\text { bet } \\
\text { wee } \\
\text { n } \\
\text { grou } \\
\text { ps }\end{array}$ & $\begin{array}{l}\text { Only gluc } \\
\text { signature } \\
\text { studied. } \neq\end{array}$ & $\begin{array}{l}\text { cortic } \\
\text { yenes }\end{array}$ & & $\begin{array}{l}\text { FKBP5,IL6, TNF, } \\
\text { CXCL2, } \\
\text { CXC L3, AND } \\
\text { CSF3 }\end{array}$ \\
\hline $\begin{array}{l}2 \\
0\end{array}$ & $\begin{array}{l}\text { Delépin } \\
\text { e et al. } \\
\text { PMID:26 } \\
208914\end{array}$ & $\begin{array}{l}20 \\
15\end{array}$ & $\begin{array}{l}\begin{array}{l}\text { Mec } \\
\mathrm{p}^{3088} \\
\text { y }\end{array} \\
\text { C57BL/6 } \\
\text { J }\end{array}$ & $\begin{array}{l}\mathrm{mal} \\
\mathrm{e}\end{array}$ & $\begin{array}{l}\text { astrocyt } \\
\text { es from } \\
\text { cortex }\end{array}$ & $\begin{array}{l}\mathrm{P} 0+ \\
\text { DIV7 }\end{array}$ & 4 & $\begin{array}{l}257 \\
p< \\
0.05\end{array}$ & 132 & 125 & $\begin{array}{l}\text { ADCY8, } \\
\text { CDON, CHGB, } \\
\text { HTR5B AND } \\
\text { MYOC } \\
\text { CCL2, GAD1, } \\
\text { LCN2, } \\
\text { NR2F2 AND } \\
\text { SHH }\end{array}$ \\
\hline
\end{tabular}

This article is protected by copyright. All rights reserved. 


\begin{tabular}{|c|c|c|c|c|c|c|c|c|c|c|c|}
\hline 1 & $\begin{array}{l}\text { Gabel } \\
\text { et al. } \\
\text { PMID:25 } \\
762136\end{array}$ & $\begin{array}{l}20 \\
15\end{array}$ & $\begin{array}{l}\text { (a) } \\
\text { Mec } \\
\text { p2tm1. } \\
\text { 1Bird } \\
\text { (b) } \\
\text { Mec } \\
\text { p2 } 2^{\mathrm{R} 306} \\
\mathrm{C} / \mathrm{y}\end{array}$ & $\begin{array}{l}\mathrm{mal} \\
\mathrm{e}\end{array}$ & $\begin{array}{l}\text { (a) } \\
\text { visual } \\
\text { cortex( } \\
\text { b) } \\
\text { cerebell } \\
\text { um }\end{array}$ & $\begin{array}{l}\text { 8-10 } \\
\text { week } \\
\text { s }\end{array}$ & $\begin{array}{l}(a) \\
3(b) \\
4\end{array}$ & & & $\mathrm{n} / \mathrm{s}$ & $\begin{array}{l}\text { CAMK2D,EPH } \\
\text { A7, SDK1 AND } \\
\text { CNTN4 }\end{array}$ \\
\hline $\begin{array}{l}2 \\
2\end{array}$ & $\begin{array}{l}\text { Hara et } \\
\text { al. } \\
\text { PMID:26 } \\
073556\end{array}$ & $\begin{array}{l}20 \\
15\end{array}$ & $\begin{array}{c}\mathrm{Mec} \\
\mathrm{p} 2-/ \mathrm{Y} \\
\mathrm{C} 57 \mathrm{BL} / 6 \\
\mathrm{FVB} / \mathrm{N} \times \\
\mathrm{C} 57 \mathrm{~B} / / 6\end{array}$ & $\begin{array}{l}\mathrm{mal} \\
\mathrm{e}\end{array}$ & $\begin{array}{l}\text { cardio- } \\
\text { vascular } \\
\text { progenit } \\
\text { orcells }\end{array}$ & DIV4 & & 2296 & $\begin{array}{l}123 \\
6\end{array}$ & $\begin{array}{l}106 \\
0\end{array}$ & $\begin{array}{l}\text { TBX5, MYH7, } \\
\text { CACNA1G, } \\
\text { AND HCN }\end{array}$ \\
\hline
\end{tabular}

\begin{tabular}{|c|c|c|c|c|c|c|c|c|c|c|c|}
\hline $\begin{array}{l}2 \\
3\end{array}$ & $\begin{array}{l}\text { Kishi et } \\
\text { al } \\
\text { PMID:2 } \\
682181 \\
6\end{array}$ & $\begin{array}{l}20 \\
16\end{array}$ & $\begin{array}{l}\text { Mecp } \\
2-/ Y \\
\text { C57BL/6 }\end{array}$ & $\begin{array}{l}\mathrm{mal} \\
\mathrm{e}\end{array}$ & $\begin{array}{l}\text { cortical } \\
\text { callosal } \\
\text { projecti } \\
\text { on } \\
\text { neurons }\end{array}$ & P14 & 3 & $\begin{array}{l}37 \\
p< \\
0.0 \\
01, \\
p< \\
0.0 \\
05\end{array}$ & 18 & 19 & $\begin{array}{l}\text { KIF1B, MCF2 AND GSN } \\
\text { IRAK1 }\end{array}$ \\
\hline $\begin{array}{l}2 \\
4\end{array}$ & $\begin{array}{l}\text { Bedog } \\
\text { ni et al. } \\
\text { PMID:2 } \\
597908 \\
8\end{array}$ & $\begin{array}{l}20 \\
16\end{array}$ & $\begin{array}{l}\text { Mecp } \\
\text { 2-null } \\
\text { CD1 }\end{array}$ & $\begin{array}{l}\text { fem } \\
\text { ale }\end{array}$ & $\begin{array}{l}\text { embryo } \\
\text { nic } \\
\text { cortical } \\
\text { neurons }\end{array}$ & $\begin{array}{l}\text { E15. } \\
5\end{array}$ & 3 & $\begin{array}{l}135 \\
p< \\
0.0 \\
5\end{array}$ & & & \\
\hline $\begin{array}{l}2 \\
5\end{array}$ & $\begin{array}{l}\text { Ehrhart } \\
\text { et al. } \\
\text { PMID:2 } \\
751737 \\
1\end{array}$ & $\begin{array}{l}20 \\
16\end{array}$ & $\begin{array}{l}\text { Mecp } \\
2-/ Y \\
\text { C57BL/6 }\end{array}$ & $\begin{array}{l}\mathrm{mal} \\
\mathrm{e}\end{array}$ & data fro & n Sugin & o et & al usec & & & \\
\hline $\begin{array}{l}2 \\
6\end{array}$ & $\begin{array}{l}\text { Vacca } \\
\text { et al. } \\
\text { PMID:2 } \\
682171 \\
0\end{array}$ & $\begin{array}{l}20 \\
16\end{array}$ & $\begin{array}{l}\text { Mecp } \\
2^{2-Y Y} \\
\text { C57BL6/ } \\
J\end{array}$ & $\begin{array}{l}\mathrm{mal} \\
\mathrm{e}\end{array}$ & $\begin{array}{l}\text { embryo } \\
\text { nic } \\
\text { cortical } \\
\text { neurons }\end{array}$ & $\begin{array}{l}\text { E15 } \\
+ \text { DI } \\
\text { V3 }\end{array}$ & 3 & $\begin{array}{l}490 \\
q-\leq \\
0.0 \\
5\end{array}$ & $\begin{array}{l}39 \\
4\end{array}$ & 96 & $\begin{array}{l}\text { GFAP, ALH1L1,MEF2C } \\
\text { AND TAM } 1\end{array}$ \\
\hline
\end{tabular}

This article is protected by copyright. All rights reserved. 


\begin{tabular}{|c|c|c|c|c|c|c|c|c|c|c|c|}
\hline $\begin{array}{l}2 \\
7\end{array}$ & $\begin{array}{l}\text { Johnso } \\
\text { n et al. } \\
\text { PMID:2 } \\
892095 \\
6\end{array}$ & $\begin{array}{l}20 \\
17\end{array}$ & $\begin{array}{l}\text { (a) } \\
\text { Mecp } \\
2^{\text {TI58M- }} \\
\text { Tavi } \\
\text { (Mec } \\
\text { p2 } \\
\text { knock } \\
\text {-in) } \\
\text { (b) } \\
\text { Mecp } \\
2^{\text {R1066W- }} \\
\text { Tavi } \\
\text { (Mec } \\
\text { p2 } \\
\text { knock } \\
\text {-in) } \\
\text { C57BL6/ } \\
\text { J }\end{array}$ & $\begin{array}{l}\text { mal } \\
\text { e \& } \\
\text { fem } \\
\text { ale }\end{array}$ & $\begin{array}{l}\text { (i) } \\
\text { excitat } \\
\text { ory \& } \\
\text { inhibitor } \\
\text { y } \\
\text { cortical } \\
\text { neurons } \\
\text { (ii) } \\
\text { excitat } \\
\text { ory } \\
\text { cortical } \\
\text { neurons }\end{array}$ & $\begin{array}{l}\text { (i) } 6 \\
\text { we } \\
\text { eks } \\
\text { (ma } \\
\text { le) } \\
\text { (ii) } \\
18 \\
\text { we } \\
\text { eks } \\
\text { (fe } \\
\text { mal } \\
\text { e) }\end{array}$ & $\begin{array}{l}(\mathrm{i} \\
0 \\
4 \\
(\mathrm{i} \\
\mathrm{i} \\
\mathrm{i} \\
\geq \\
2\end{array}$ & \multicolumn{3}{|c|}{$\begin{array}{l}\text { Differs } \\
\text { between } \\
\text { groups } \neq \\
\text { FDR }<0.05\end{array}$} & \\
\hline $\begin{array}{l}2 \\
8\end{array}$ & $\begin{array}{l}\text { Pache } \\
\text { co et } \\
\text { al. } \\
\text { PMID:2 } \\
909007 \\
8\end{array}$ & $\begin{array}{l}20 \\
17\end{array}$ & $\begin{array}{l}\text { Mecp } \\
2 \text { Jae/y } \\
\text { J57BL6/ }\end{array}$ & $\begin{array}{l}\text { mal } \\
\mathrm{e}\end{array}$ & cortex & P60 & 4 & $\begin{array}{l}391 \\
\mathrm{q}< \\
0.0 \\
5\end{array}$ & $\begin{array}{l}13 \\
2\end{array}$ & $\begin{array}{l}25 \\
9\end{array}$ & $\begin{array}{l}\text { ARHGDIG, CACNB3, } \\
\text { CALB1, FABP7, FKBP5, } \\
\text { ITM2A, MSMO1, PLAGL1, } \\
\text { PVALB, SGK1 }\end{array}$ \\
\hline $\begin{array}{l}2 \\
9\end{array}$ & $\begin{array}{l}\text { Zhao } \\
\text { et al. } \\
\text { PMID:2 } \\
836730 \\
7\end{array}$ & $\begin{array}{l}20 \\
17\end{array}$ & $\begin{array}{l}\text { Mecp } \\
2^{+1-} \\
\text { C57BL/6 }\end{array}$ & $\begin{array}{l}\text { fem } \\
\text { ale }\end{array}$ & $\begin{array}{l}\text { microgli } \\
\text { a from } \\
\text { whole } \\
\text { brain }\end{array}$ & $\begin{array}{l}\text { (a) } \\
5 \\
\text { we } \\
\text { eks } \\
\text { (b) } \\
24 \\
\text { we } \\
\text { eks }\end{array}$ & 6 & $\begin{array}{l}\text { (a) } \\
464 \\
\\
\text { (b) } \\
79 \\
\\
p< \\
0.0 \\
5\end{array}$ & $\begin{array}{l}\text { a } \\
)^{2} \\
78 \\
(b \\
)_{42}\end{array}$ & $\begin{array}{l}\text { (a } \\
) \\
38 \\
6 \\
(b \\
\text { b } \\
37\end{array}$ & $\begin{array}{l}\text { A) SEMA3B, NOV, } \\
\text { DNAJ A1, VCAM1, MGP } \\
\text { CBLN3, REINLA, RNF17. } \\
\text { CASS4, IFIT2, } \\
\text { B)NFKBID, RIAN, AND LSP1 }\end{array}$ \\
\hline $\begin{array}{l}3 \\
0\end{array}$ & $\begin{array}{l}\text { Mellén } \\
\text { et al } \\
\text { PMID:2 } \\
884794 \\
7\end{array}$ & $\begin{array}{l}20 \\
17\end{array}$ & $\begin{array}{l}\text { Mecp } \\
2^{\mathrm{tm} 1.1 \mathrm{Bir}} \\
\mathrm{d} \\
\text { C57B } \\
\text { L/6J }\end{array}$ & $\begin{array}{l}\mathrm{mal} \\
\mathrm{e}\end{array}$ & $\begin{array}{l}\text { cerebel } \\
\text { lum }\end{array}$ & $\begin{array}{l}7-12 \\
\text { we } \\
\text { eks }\end{array}$ & 4 & $n / s$ & & & \\
\hline $\begin{array}{l}3 \\
1\end{array}$ & $\begin{array}{l}\text { Osenb } \\
\text { erg et } \\
\text { al. } \\
\text { PMID: } \\
297693 \\
30\end{array}$ & $\begin{array}{l}20 \\
18\end{array}$ & $\begin{array}{l}\text { a)Me } \\
\text { cp2tm } \\
\text { 1.1Bird } \\
\text { b) } \\
\text { Mecp } \\
\text { 2-1Y } \\
\text { C57// } \\
\text { BL6 }\end{array}$ & $\mathrm{e}^{\mathrm{mal}}$ & $\begin{array}{l}\text { a)cortic } \\
\text { al } \\
\text { neurons } \\
\text { b)hippo } \\
\text { campu } \\
\text { s }\end{array}$ & $\begin{array}{l}\text { a)P( } \\
0- \\
1)+1 \\
0 \\
\text { day } \\
\text { s } \\
\\
\text { b) } 7 \\
\text { we } \\
\text { eks }\end{array}$ & 3 & $\begin{array}{l}\text { a)2 } \\
7 \\
\text { b)8 } \\
0 \\
\\
\text { q- } \\
\text { val } \\
\text { ue } \\
< \\
0.0 \\
5\end{array}$ & $\begin{array}{l}\text { a) } \\
8 \\
\text { b) } \\
48\end{array}$ & $\begin{array}{l}\text { a) } \\
19 \\
\text { b) } \\
32\end{array}$ & $\begin{array}{l}\text { HAPLN1,STUM, G FRA1, } \\
\text { IQ GAP3,BRC A1,UHRF1,C } \\
\text { DC20,FBLN2,STEAP4 } \\
\text { SERPINB2,G PRC 5A,G M20 } \\
\text { 594,G M5778,MREG,RBPM } \\
\text { S }\end{array}$ \\
\hline
\end{tabular}

This article is protected by copyright. All rights reserved. 


\begin{tabular}{|c|c|c|c|c|c|c|c|c|c|c|c|}
\hline $\begin{array}{l}3 \\
2\end{array}$ & $\begin{array}{l}\text { Rentha } \\
\text { I et al. } \\
\text { PMID: } \\
304554 \\
58\end{array}$ & $\begin{array}{l}20 \\
18\end{array}$ & $\begin{array}{l}\text { Mecp } \\
2^{\mathrm{tm} 1.1 \mathrm{Bir}} \\
\mathrm{d}\end{array}$ & $\begin{array}{l}\text { a)Fe } \\
\text { mal } \\
\text { e } \\
\text { b)M } \\
\text { ale }\end{array}$ & $\begin{array}{l}\text { Visual } \\
\text { cortex }\end{array}$ & $\begin{array}{l}\text { a) } \\
12- \\
20 \\
\text { we } \\
\text { eks } \\
\text { b) } 8 \\
\text { we } \\
\text { eks }\end{array}$ & 5 & $\begin{array}{l}\text { a) } 7 \\
34 \\
\text { b) }> \\
100 \\
0\end{array}$ & $\begin{array}{l}\text { a) } \\
36 \\
6\end{array}$ & $\begin{array}{l}\text { a) } \\
36 \\
8\end{array}$ & \\
\hline $\begin{array}{l}3 \\
3\end{array}$ & $\begin{array}{l}\text { Sanfeli } \\
\text { u et al. } \\
\text { PMID:3 } \\
111048 \\
4\end{array}$ & $\begin{array}{l}20 \\
19\end{array}$ & $\begin{array}{l}\text { Mecp } \\
2^{\mathrm{tm} 1.1 \mathrm{Bir}} \\
\mathrm{d} \\
\text { C57// } \\
\text { BL6 }\end{array}$ & $\begin{array}{l}\text { mal } \\
\mathrm{e}\end{array}$ & $\begin{array}{l}\text { a) brain } \\
\text { b) } \\
\text { blood }\end{array}$ & $\begin{array}{l}7 \\
\text { we } \\
\text { eks }\end{array}$ & 3 & $\begin{array}{l}\text { a) } \\
81 \\
\text { b) } \\
205 \\
\\
p< \\
0.0 \\
5\end{array}$ & $\begin{array}{l}\text { a) } \\
44 \\
\\
\text { b) } \\
10 \\
5\end{array}$ & $\begin{array}{l}\text { a) } \\
37 \\
\\
\text { b) } \\
10 \\
0\end{array}$ & UBE2V1, SERPIN1 \\
\hline
\end{tabular}

Proteomic studies

\begin{tabular}{|c|c|c|c|c|c|c|c|c|c|c|}
\hline $\begin{array}{l}\mathbf{N} \\
\mathbf{0}\end{array}$ & Reference & $\begin{array}{l}\text { Ye } \\
\text { ar }\end{array}$ & $\begin{array}{l}\text { Transgenic } \\
\text { Model } \\
\text { \& Genetic } \\
\text { Background }\end{array}$ & $\begin{array}{l}\text { Gend } \\
\text { er }\end{array}$ & $\begin{array}{l}\text { Cell } \\
\text { source }\end{array}$ & $\begin{array}{l}\text { Age } \\
\text { when } \\
\text { studi } \\
\text { ed }\end{array}$ & $\begin{array}{l}\text { No of } \\
\text { sampl } \\
\text { es }\end{array}$ & $\begin{array}{l}\text { DE at } \\
\text { statistic } \\
\text { al cut- } \\
\text { off }\end{array}$ & IE & RE \\
\hline 1 & $\begin{array}{l}\text { Matarazz } \\
\text { o \& } \\
\text { Ronnett } \\
\text { PMID: } \\
\text { 15128950 }\end{array}$ & $\begin{array}{l}200 \\
4\end{array}$ & Mecp2-null & male & $\begin{array}{l}\text { a) } \\
\text { olfactor } \\
\text { y } \\
\text { epitheli } \\
\text { um } \\
\text { (b) } \\
\text { olfactor } \\
\text { y bulb }\end{array}$ & $\begin{array}{l}\text { (i) } 2 \\
\text { week } \\
\text { s (ii) } 4 \\
\text { week } \\
\text { s }\end{array}$ & 3 & $\begin{array}{l}27(a) \\
(\mathrm{i}), \\
67 \\
\text { (b)(i) } \\
6 \\
(\mathrm{a})(\mathrm{ii}) \\
\text { 1(b)(i } \\
\text { i) }\end{array}$ & $\begin{array}{l}13 \\
\text { (a) } \\
\text { (i), } \\
64 \\
\text { (b) } \\
\text { (i) } \\
\\
1 \text { (a) } \\
\text { (ii) }\end{array}$ & $\begin{array}{l}14(\mathrm{a}) \\
\text { (i), } 3 \\
\text { (b)(i) } \\
5 \\
\text { (a)(ii),1(b } \\
\text { (ii) }\end{array}$ \\
\hline 2 & $\begin{array}{l}\text { Cortela } \\
\text { zzo et } \\
\text { al. } \\
\text { PMID: } \\
285929 \\
17\end{array}$ & $\begin{array}{l}201 \\
7\end{array}$ & $\begin{array}{l}\text { Меср2308 } \\
\text { B6.129S } \\
\text { MeCP2tm1H } \\
\text { zo/J }\end{array}$ & $\begin{array}{l}\text { femal } \\
\mathrm{e}\end{array}$ & plasma & $\begin{array}{l}10-12 \\
\text { mont } \\
\text { hs }\end{array}$ & 3 & $\begin{array}{l}10 \\
p< \\
0.05\end{array}$ & 6 & 4 \\
\hline
\end{tabular}

This article is protected by copyright. All rights reserved. 


\begin{tabular}{|c|c|c|c|c|c|c|c|c|c|c|}
\hline 3 & $\begin{array}{l}\text { Pache } \\
\text { co et } \\
\text { al. } \\
\text { PMID: } \\
290900 \\
78\end{array}$ & $\begin{array}{l}201 \\
7\end{array}$ & $\begin{array}{l}\text { Mecp2 } \\
\text { Jae/y } \\
\text { C57BL6/J }\end{array}$ & male & cortex & P60 & 4 & $\begin{array}{l}465 \\
p< \\
0.1\end{array}$ & 299 & 166 \\
\hline
\end{tabular}

Footnotes:

$\mathrm{P}=$ Post-natal; $\mathrm{E}=$ Embryonic $;$ DIV = days in vitro; PMID = Pubmed identifier, $\mathrm{n}=$ Mecp2 - null;

$\mathrm{DE}=$ Differential expression; $\mathrm{IE}=$ Increa sed expression; $\mathrm{RE}=$ Reduc ed Expression

$\mathrm{n} / \mathrm{a}$ - data not available

n/s- not specified

‡-more data available in paper

$\S$ - 4 neuronal cell types: (1) layer 5 thic $k$ tufted pyramidal neurons in motor cortex; (2) fast-spiking

parva lbumin-positive intemeurons in motor cortex; (3) nora drenerg ic loc us cenuleus neurons; (4) cerebellar purkinje

cells

This article is protected by copyright. All rights reserved. 


\section{University Library}

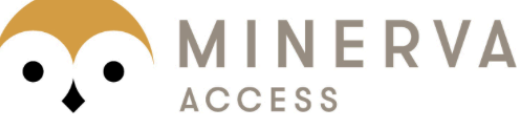

A gateway to Melbourne's research publications

Minerva Access is the Institutional Repository of The University of Melbourne

Author/s:

Krishnaraj, R;Haase, F;Coorey, B;Luca, EJ;Wong, I;Boyling, A;Ellaway, C;Christodoulou, J;Gold, WA

Title:

Genome-wide transcriptomic and proteomic studies of Rett syndrome mouse models identify common signaling pathways and cellular functions as potential therapeutic targets

Date:

2019-08-23

Citation:

Krishnaraj, R., Haase, F., Coorey, B., Luca, E. J., Wong, I., Boyling, A., Ellaway, C., Christodoulou, J. \& Gold, W. A. (2019). Genome-wide transcriptomic and proteomic studies of Rett syndrome mouse models identify common signaling pathways and cellular functions as potential therapeutic targets. HUMAN MUTATION, 40 (12), pp.2184-2196. https:// doi.org/10.1002/humu.23887.

Persistent Link:

http://hdl.handle.net/11343/286323 